\title{
Functionalized Homoleptic cis- and trans-C,N-ortho-Chelated Aminoaryl Platinum(II) Complexes
}

\author{
Catelijne H. M. Amijs, ${ }^{\dagger}$ Gerard P. M. van Klink, ${ }^{\dagger}$ Martin Lutz, ${ }^{\dagger}$ \\ Anthony L. Spek, ${ }^{\ddagger}$, and Gerard van Koten*,† \\ Department of Organic Chemistry and Catalysis, Debye Institute, and Department of Crystal \\ and Structural Chemistry, Bijvoet Center for Biomolecular Research, Utrecht University, \\ Padualaan 8, 3584 CH Utrecht, The Netherlands
}

Received March 1, 2005

\begin{abstract}
For the synthesis of corner building blocks with a $90^{\circ}$ angle, to be used for the construction of larger structures, several homoleptic platinum(II) complexes $\left[\mathrm{Pt}\left(\eta^{2}-\mathrm{C}, \mathrm{N}\right)_{2}\right](\mathbf{1 0}-\mathbf{1 4})$, as both cis- and trans-isomers, have been prepared starting from newly synthesized ortholithiated (dimethylamino)methyl arene ligands. The aryl groups of these arylplatinum(II) complexes contain additional substituents such as halides or methyl, naphthyl, or (dimethylamino)methyl groups. With these functionalities on the aryl rings the cis/trans ratio could be tuned. The presence of steric groups ortho to the metal center (methyl or naphthyl) favors the formation of planar-chiral cis-isomers. The trans-isomers isomerize irreversibly to the thermodynamically favored cis-isomers upon heating. The arylplatinum(II) complexes were used in various substitution reactions. Addition of a stronger coordinating ligand changes the denticity of the $C, N$-attached ligands. The halide functionalities were exploited for chemoselective lithiation and subsequent transmetalation reactions in order to synthesize the $\mathrm{SnMe}_{3}$-functionalized $\left[\mathrm{Pt}(\mathrm{C}, \mathrm{N})_{2}\right]$ complexes. A Suzuki-Miyaura C-C coupling reaction on one of these complexes was also performed, resulting in the preparation of a mixed trinuclear palladium/platinum complex (25). The crystal structure determinations of four functionalized cis- $\left[\mathrm{Pt}(\mathrm{C}, \mathrm{N})_{2}\right]$ complexes, cis-12-Et $\mathrm{t}_{2} \mathrm{O}$, cis-14. $x \mathrm{C}_{6} \mathrm{H}_{6}, \mathbf{1 9}$, and $\mathbf{2 5} \cdot x \mathrm{CH}_{2} \mathrm{Cl}_{2}$, are reported. With these structures it is shown that depending on the substituents, the degree of planarity around the platinum center can be tuned.
\end{abstract}

\section{Introduction}

Two important factors for a rational design of coordination-based supramolecular entities are the symmetry and the shape of the assembly. These two factors are determined solely by the type and properties of the building blocks. For two-dimensional structures two types of building blocks are required: (1) linear ditopic units, which contain reactive sites with a $180^{\circ}$ orientation relative to each other, and (2) angular ditopic units, possessing reactive sites with other desirable angles. Generally, building blocks consist of either an electrondeficient metal center as an acceptor or an organic ligand with Lewis-base functionalities (often pyridine) as donor. Square-planar platinum(II) and palladium(II) centers with coordination angles of approximately $180^{\circ}$ or $90^{\circ}$ are frequently used as linear or corner acceptor units, respectively. Only in a few cases have organometallic complexes been used as donor building blocks. In these cases, the metal center itself is not used as an acceptor unit, but instead the metal center directs the orientation of the donor units via the attached

\footnotetext{
* Corresponding author. Phone: +31-30-2533120. Fax: +31-302523615. E-mail: g.vankoten@chem.uu.nl.

$\dagger$ Debye Institute.

$¥$ Bijvoet Center for Biomolecular Research.

$\S$ Corresponding author for crystallographic data. Phone: +31-302532538. Fax: +31-30-2523940. E-mail: a.l.spek@chem.uu.nl.
}

ligands. The advantage of such complexes is that they have predefined structures, e.g., linear or angular in the case of square-planar complexes, as well as high stability as compared to coordination complexes. It should be noted that especially the $90^{\circ}$ angle is rarely observed in entirely organic donor compounds. Examples of rightangled structures are complexes $\mathbf{A}$ and $\mathbf{B}$ (Chart 1) reported by Stang and co-workers. ${ }^{1}$ For our research, we have chosen to use the homoleptic platinum(II) complex $\left[\mathrm{Pt}(\mathrm{dmba})_{2}\right]\left(\mathrm{dmba}=\left[\mathrm{C}_{6} \mathrm{H}_{4}\left(\mathrm{CH}_{2} \mathrm{NMe}_{2}\right)-2\right]^{-}\right)(\mathbf{C}$, $\mathrm{X}=\mathrm{R}=\mathrm{H}(\mathbf{1})$, Chart 1$)^{2}$ as a corner building block with a predefined $90^{\circ}$ angle. The choice for this system is motivated by the possibility to introduce donor functionalities on both the two arene rings ${ }^{3}$ and the nitrogen donor substituents. ${ }^{2,4}$ Our strategy has been to prepare the organometallic precursor complexes $\left[\mathrm{Pt}(\mathrm{C}, \mathrm{N})_{2}\right](\mathrm{C}, \mathrm{N}$ $=C, N$-ortho-chelating ligand) and to functionalize these in subsequent reactions. This reaction sequence starts with the synthesis of various $C, N$-chelating ligands

(1) (a) Manna, J.; Whiteford, J. A.; Stang, P. J. J. Am. Chem. Soc. 1996, 118, 8731-8732. (b) Müller, C.; Whiteford, J. A.; Stang P. J. J. Am. Chem. Soc. 1998, 120, 9827-9837. (c) Stang, P. J. Chem. Eur. J. 1998, 4, 19-27.

(2) Longoni, G.; Fantucci, P.; Chini, P.; Canziani, F. J. Organomet. Chem. 1972, 39, 413-425.

(3) Rodríguez, G.; Albrecht, M.; Schoenmaker, J.; Ford, A.; Lutz, M.; Spek, A. L.; van Koten, G. J. Am. Chem. Soc. 2002, 124, 5127-5138.

(4) Jude, H.; Krause Bauer, J. A.; Connick, W. B. Inorg. Chem. 2002 $41,2275-2281$. 
Chart 1. Organoplatinum Corner Complexes

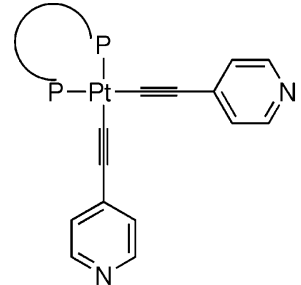

A

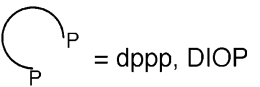

having a halide substituent on the arene ring, which allows further functionalization by $\mathrm{C}-\mathrm{C}$ bond formation reactions such as Suzuki-Miyaura reactions. In this paper we describe the synthesis and characterization of various types of $\left[\mathrm{Pt}(\mathrm{C}, \mathrm{N})_{2}\right](\mathbf{C}, \mathrm{X}=\mathrm{Br}, \mathrm{I}, \mathrm{R}=\mathrm{H}, \mathrm{Me}$, $\mathrm{CH}_{2} \mathrm{NMe}_{2}$ ) complexes and their use in subsequent lithiation and transmetalation reactions. It was demonstrated that $\mathrm{C}-\mathrm{C}$ coupling reactions on these organometallic complexes without affecting the metalcarbon bond are possible as well. We also describe the synthesis of $\left[\mathrm{Pt}(\mathrm{C}, \mathrm{N})_{2}\right]$ complexes with planar chirality, which is induced by introduction of steric bulk on the aryl rings.

\section{Results and Discussion}

Synthesis of $\left[\operatorname{Pt}(\mathbf{C}, \mathbf{N})_{2}\right]$ Complexes. The commonly applied route for the synthesis of homo- and heteroleptic bis-cyclometalated $\left[\mathrm{M}(\mathrm{C}, \mathrm{N})_{2}\right]$ complexes is the introduction of the metal center via a transmetalation reaction. Previous reports showed that homoleptic compounds can be prepared via reaction of an organolithium or Grignard reagent with either a cis- or trans- $\left[\mathrm{PtX}_{2} \mathrm{~L}_{2}\right]$ salt $(\mathrm{X}$ $\left.=\mathrm{Br}, \mathrm{Cl}, \mathrm{L}=\mathrm{cod}, \mathrm{SEt}_{2}, \mathrm{SMe}_{2}\right){ }^{2,5}$ while the synthesis of heteroleptic complexes involved reaction of a dinuclear, halide-bridged, complex $[\mathrm{MX}(\mathrm{C}, \mathrm{N})]_{2}(\mathrm{M}=\mathrm{Pt}, \mathrm{Pd}, \mathrm{X}=$ $\mathrm{Br}, \mathrm{Cl})$ with an organolithium, ${ }^{6}$-mercury, ${ }^{7,8}$ or -zinc ${ }^{9}$ complex. Various new 2,5-bis (dimethylamino)methyl $\}$ arene ligands $(\mathrm{C}, \mathrm{N})$, which are functionalized at the 1and 4-positions with halide substituents, were designed for the synthesis of the platinum complexes (Scheme 1). The choice of halide, bromide or iodide, ortho to the potentially chelating (dimethylamino)methyl group, was made in such way that regioselective metalation would occur at that position. The second halide would thereby be unaffected, as a $\mathrm{C}-\mathrm{I}$ bond is more reactive than the $\mathrm{C}-\mathrm{Br}$ bond in both oxidative addition and halidelithium exchange reactions.

The various amine ligands were prepared starting from their methyl analogues by benzylic bromination (Scheme 1). The synthesis of the starting compounds 2-4 was carried out following a new, highly efficient

(5) Wehman-Ooyevaar, I. C. M.; Grove, D. M.; Kooijman, H.; van der Sluis, P.; Spek, A. L.; van Koten, G. J. Am. Chem. Soc. 1992, 114 9916-9924.

(6) Valk, J.-M. Maassarani, F.; van der Sluis, P.; Spek, A. L.; Boersma, J.; van Koten, G. Organometallics 1994, 13, 2320-2329.

(7) Berger, A.; Djukic, J.-P.; Pfeffer, M. Organometallics 2003, 22 , 5243-5260.

(8) van der Ploeg, A. F. M. J.; van Koten, G.; Vrieze, K. J. Organomet. Chem. 1981, 222, 155-174.

(9) Valk, J.-M.; Boersma, J.; van Koten, G. Organometallics 1996 $15,4366-4372$

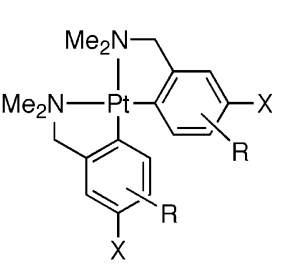

B
C

$X=$ halide

$\mathrm{R}=$ methyl, naphthyl, $\mathrm{CH}_{2} \mathrm{NMe}_{2}$

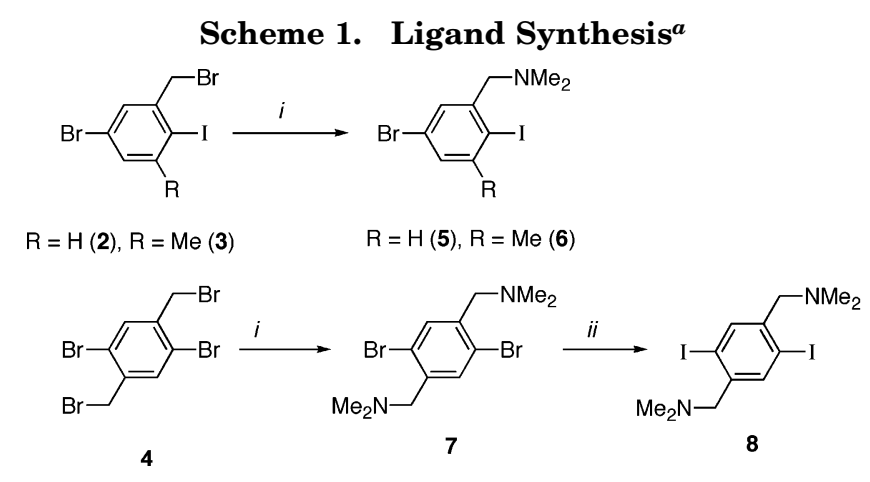

a (i) $\mathrm{HNMe}_{2}, \mathrm{Et}_{2} \mathrm{O}, 2 \mathrm{~h}$; (ii) $n$-BuLi, $\mathrm{Et}_{2} \mathrm{O},-78^{\circ} \mathrm{C} \rightarrow \mathrm{RT}, 1$ h, $\mathrm{C}_{2} \mathrm{H}_{4} \mathrm{I}_{2}$.

procedure. $^{10}$ Nucleophilic substitution of $\mathbf{2 - 4}$ with $\mathrm{HNMe}_{2}$ yielded the benzylic amines 5, 6, and 7, respectively. The preparation of 1,4-diiodo-2,5-bis\{(dimethylamino)methyl \}benzene (8) was achieved via double lithiation of 7 followed by quenching of the dilithio compound with 1,2-diiodoethane.

Lithiation of benzylamines 5-8 with 1 equiv of $n$-BuLi in $\mathrm{Et}_{2} \mathrm{O}$ occurred in all cases at the desired ortho $\mathrm{C}$-halide position, without any trace of $\mathrm{C}-\mathrm{H}$ activation. Quenching of the respective reaction mixtures with $\mathrm{S}_{2^{-}}$ $\mathrm{Me}_{2}$ and subsequent analysis of the ortho-MeS products by ${ }^{1} \mathrm{H}$ NMR and GC-MS spectroscopy showed a unique chemoselectivity for lithiation at the $\mathrm{C}-\mathrm{I}$ bond for both 5 and $\mathbf{6}$.

Ligands 5-8 and 1-bromo-2-\{(dimethylamino)methyl $\}$ naphthalene $(\mathbf{9})^{11}$ were used to synthesize the corresponding $\left[\mathrm{Pt}(\mathrm{C}, \mathrm{N})_{2}\right]$ complexes by sequential chemoselective lithiation and transmetalation reactions. The transmetalation reactions were performed by reacting the in situ prepared lithium complexes with 0.5 equiv of trans-[ $\left.\mathrm{PtCl}_{2}\left(\mathrm{SMe}_{2}\right)_{2}\right]$ (Scheme 2). Full conversion to the respective homoleptic complexes 10-14 was obtained within $3 \mathrm{~h}$. The complexes were obtained as a mixture of cis- and trans-isomers (see Table 1), except for 11, for which only the formation of the cis-isomer was observed. This is in accordance with results reported by Longoni et al., who showed that upon reacting the lithium complex $[\mathrm{Li}(\mathrm{dmba})]$ with trans- $\left[\mathrm{PtCl}_{2}\right.$ $\left.\left(\mathrm{SMe}_{2}\right)_{2}\right]$, a mixture of cis- and trans-isomers of the nonfunctionalized $\left[\mathrm{Pt}(\mathrm{dmba})_{2}\right](\mathbf{1})$ was obtained (Table 1 , entry 1$)^{2}$

A mechanism for the formation of homoleptic platinum complexes was proposed by von Zelewsky and co-

(10) Amijs, C. H. M.; van Klink, G. P. M.; van Koten, G. Green Chem. 2003, 5, 470-474.

2303. 
Scheme 2. Synthesis of cis- and trans-[Pt(C,N $\left.)_{2}\right]^{a}$
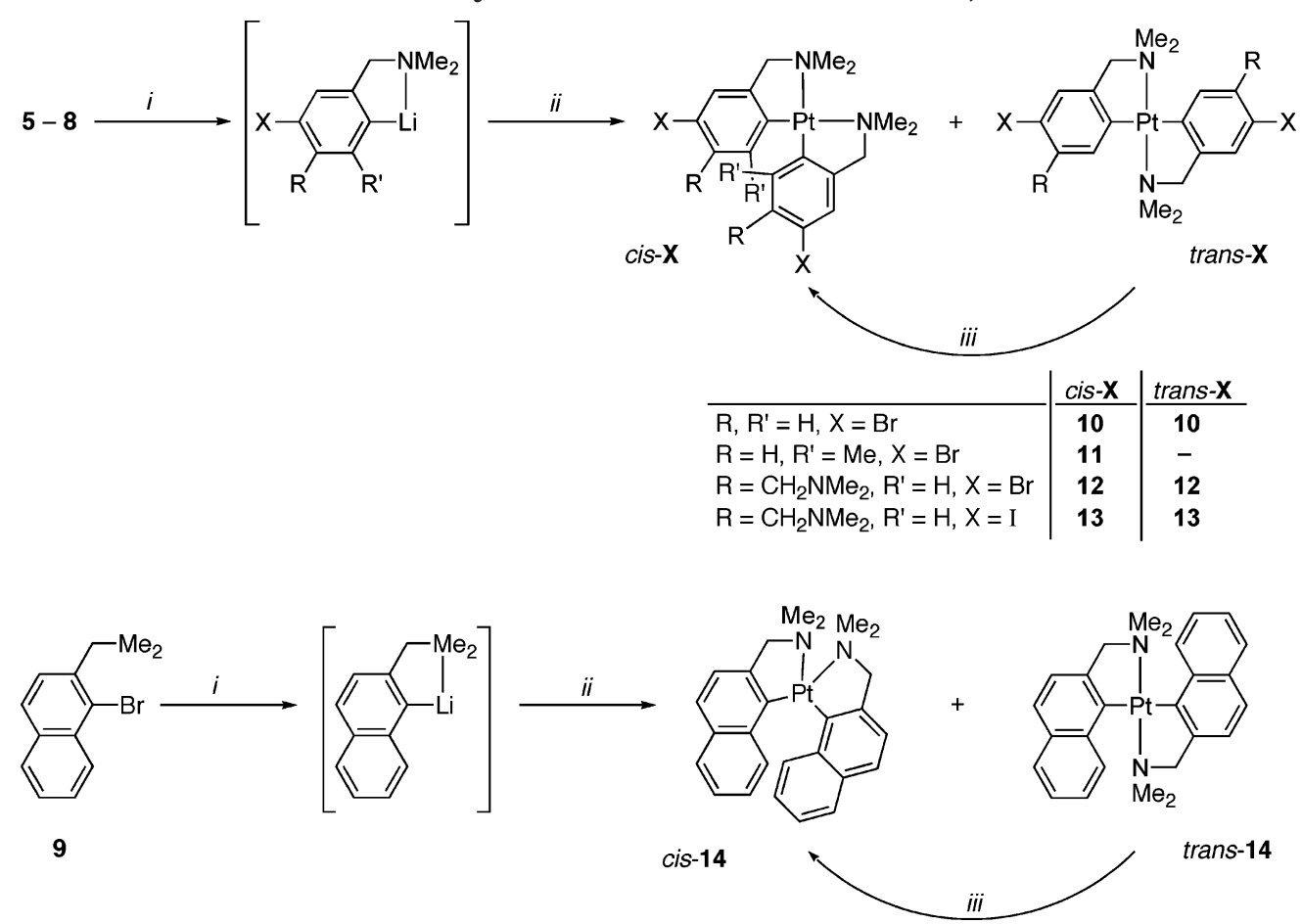
h.

${ }^{a}$ (i) $n$ - $\mathrm{BuLi}, \mathrm{Et} 2 \mathrm{O},-78{ }^{\circ} \mathrm{C}, 10 \mathrm{~min}$; (ii) 0.5 equiv $\left[\mathrm{PtCl}_{2} \mathrm{~L}_{2}\right]\left(\mathrm{L}_{2}=\operatorname{cod}, 2\left(\mathrm{SMe}_{2}\right)\right), \mathrm{Et}_{2} \mathrm{O},-78{ }^{\circ} \mathrm{C} \rightarrow \mathrm{RT}, 3 \mathrm{~h}$; (iii) toluene, $\Delta T, 3-16$

Table 1. Observed cis/trans Ratios When Using Either cis-[PtCl 2 (cod)] or trans-[PtCl $\left.{ }_{2}\left(\mathrm{SMe}_{2}\right)_{2}\right]$ as $\mathrm{Starting}$ Reagent

\begin{tabular}{|c|c|c|c|c|c|}
\hline \multirow[b]{2}{*}{ entry } & \multirow{2}{*}{$\frac{\text { Pt complex }}{\left[\mathrm{Pt}(\mathrm{C}, \mathrm{N})_{2}\right]}$} & \multirow{2}{*}{$\begin{array}{c}\text { substituents } \\
\mathrm{R}, \mathrm{R}^{\prime}, \mathrm{X}^{b}\end{array}$} & \multicolumn{2}{|c|}{ ratio cis/trans ${ }^{a}$} & \multirow[b]{2}{*}{ ref } \\
\hline & & & {$\left[\right.$ trans $\left.-\mathrm{PtCl}_{2}\left(\mathrm{SMe}_{2}\right)_{2}\right]$} & {$\left[c i s-\mathrm{PtCl}_{2}(\operatorname{cod})\right]$} & \\
\hline 1 & 1 & $\mathrm{H}, \mathrm{H}, \mathrm{H}$ & $75 / 25$ & & 2 \\
\hline 2 & 10 & $\mathrm{H}, \mathrm{H}, \mathrm{Br}$ & $85 / 15$ & $100 / 0$ & $c$ \\
\hline 3 & 11 & $\mathrm{H}, \mathrm{Me}, \mathrm{Br}$ & $100 / 0$ & $100 / 0$ & $c$ \\
\hline 4 & 12 & $\mathrm{CH}_{2} \mathrm{NMe}_{2}, \mathrm{H}, \mathrm{Br}$ & $40 / 60^{d}$ & $100 / 0$ & $c$ \\
\hline 5 & 13 & $\mathrm{CH}_{2} \mathrm{NMe}_{2}, \mathrm{H}, \mathrm{I}$ & $45 / 55^{d}$ & $100 / 0$ & $c$ \\
\hline 6 & 14 & naphthyl & $85 / 15^{d}$ & $100 / 0$ & $c$ \\
\hline 7 & $15^{e}$ & $\mathrm{H}, \mathrm{H}, \mathrm{H}^{e}$ & & $100 / 0$ & 5 \\
\hline
\end{tabular}

${ }^{a}$ After analysis of the reaction mixtures by ${ }^{1} \mathrm{H}$ NMR spectroscopy in $\mathrm{CDCl}_{3} .{ }^{b}$ Substituents as depicted in Scheme $2 .{ }^{c}$ This work. ${ }^{d} \mathrm{C}_{6} \mathrm{D}_{6}$ solutions. ${ }^{e} \mathrm{C}, \mathrm{N}=\left[\mathrm{C}_{6} \mathrm{H}_{4}\left(\mathrm{CH}(\mathrm{Me}) \mathrm{NMe}_{2}\right)-2-(R)\right]^{-}$.

Scheme 3. Mechanism for the Formation of Homoleptic Platinum Complexes as Proposed by von Zelewsky et al. ${ }^{12}$

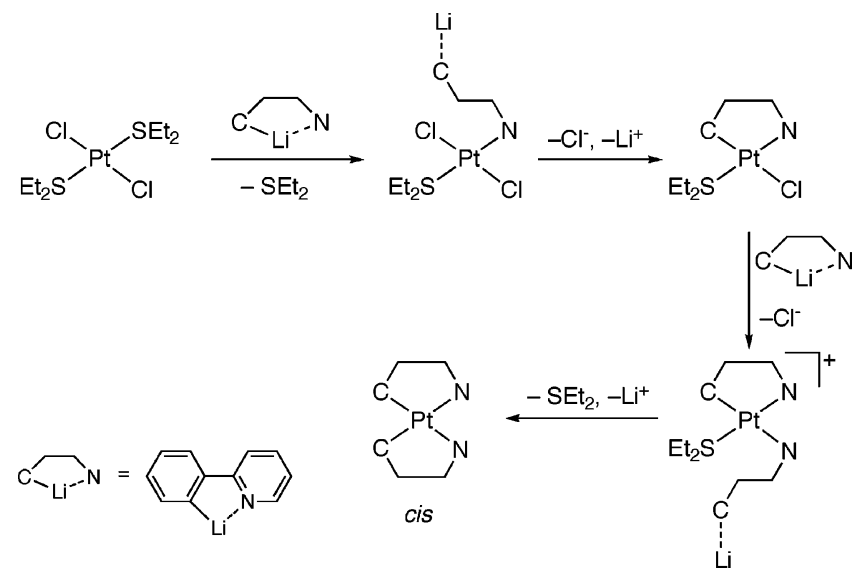

workers (Scheme 3), who obtained only cis-isomers of $\left[\mathrm{Pt}(\mathrm{C}, \mathrm{N})_{2}\right]$ even when starting from trans-[PtCl $\left.2\left(\mathrm{SEt}_{2}\right)_{2}\right]{ }^{12}$

(12) Jolliet, P.; Gianni, M.; von Zelewsky, A.; Bernardelli, G.; Stoeckli-Evans, H. Inorg. Chem. 1996, 35, 4883-4888.
This mechanism is based on the trans-effect of bound ligands. According to this mechanism, in the first step one lithiated $C, N$-ligand is bound to the metal center by its nitrogen atom, causing liberation of a diethyl sulfide molecule. The chelation is completed with the formation of a metal-carbon bond and is followed by elimination of one chloride anion. The strong trans-effect of the bonded carbon atom directs the coordination of the second nitrogen atom into the trans-position, and formation of the second metal-carbon bond yields cis$\left[\mathrm{Pt}(\mathrm{C}, \mathrm{N})_{2}\right]$.

Although it is likely that the trans-effect does play an important role in the reaction mechanism, the present results show that other factors also affect the cis/trans-preference during the formation of these complexes. Most likely, the difference lies in the nature of the used $C, N$-ligands. Whereas von Zelewsky used rigid arylpyridine ligands, we and others used the more flexible dmba-type ligands. We found that the presence of substituents on the arene rings strongly influences the cis/trans ratio. As compared to parent complex $\mathbf{1}$, a slightly higher ratio was observed for the para-bromosubstituted complex 10 (Table 1, entry 2). Interestingly, 
the presence of a meta substituent in addition to the para halide group favors the formation of the transisomers (entries 4 and 5). In contrast, substituents at the ortho-positions favored the formation of cis-isomers (entries 3 and 6), most likely due to steric hindrance. Apparently, the steric interference between the orthosubstituents and the $\mathrm{Me}_{2} \mathrm{~N}$ groups in trans-11 and trans-14 destabilizes the trans-complexes with respect to the cis-complexes. This is in accordance with earlier observations for complexes with substantial sterically interacting ligands. Also in these cases, only cis-isomers were formed. ${ }^{2,12,13}$ For example, the $N, N$-ethyl substituents on the benzylamine group in the closely related complex cis- $\left[\mathrm{Pt}(\mathrm{deba})_{2}\right]\left(\mathrm{deba}=\left[\mathrm{C}_{6} \mathrm{H}_{4}\left(\mathrm{CH}_{2} \mathrm{NEt}_{2}\right)-2\right]^{-}\right)$are sufficiently large to direct the reaction toward the complete formation of only the cis-isomer using reaction conditions similar to those applied for the synthesis of 1. ${ }^{2}$

The formation of $\mathbf{1 0}$ and $\mathbf{1 2}$ was monitored by taking samples of the reaction mixture at regular intervals. ${ }^{1} \mathrm{H}$ NMR spectra of these samples showed that the cis / trans ratio did not change during the reaction.

When the transmetalation reactions were performed with $c i s-\left[\mathrm{PtCl}_{2}(\operatorname{cod})\right]$, only $c i s$-isomers were obtained without any trace of trans-complexes, as was already observed by Wehman-Ooyevaar et al., for the synthesis of cis- $\left[\mathrm{Pt}\left\{\mathrm{C}_{6} \mathrm{H}_{4}\left(\mathrm{CH}(\mathrm{Me}) \mathrm{NMe}_{2}\right)-2-(R)\right\}_{2}\right] \quad$ (15, Table 1, entry 7). ${ }^{5}$ In the mechanism, starting from a $\mathrm{cis}$ complex, in the first step one $C, N$-ligand is bound to the metal center by its nitrogen atom, thereby replacing one of the coordinated olefinic groupings of the initially $\eta^{2}$ bidentate-bonded cod ligand. Subsequently, the metalcarbon bond is formed and the strong trans-effect of the carbon atom directs the coordination of the second nitrogen atom to the trans-position. This nitrogen atom replaces the $\eta^{1}$-monodentate-bonded cod ligand, resulting in the formation of $c i s-\left[\mathrm{Pt}(\mathrm{C}, \mathrm{N})_{2}\right]$.

Separation of the cis- from the trans-isomers was possible due to the considerable solubility differences. The trans-complexes are generally more soluble in various solvents such as benzene, toluene, and THF. A convenient method for getting the pure cis-complex involved washing of the reaction mixture with THF or precipitation of the cis-product from a $\mathrm{CH}_{2} \mathrm{Cl}_{2} / \mathrm{Et}_{2} \mathrm{O}$ mixture. Unfortunately, it was not possible to obtain completely pure trans-isomers, as small amounts of the cis-isomers remained present in the THF washing layers.

The synthesis of homoleptic complexes via a two-step procedure was also investigated. If successful, this would create new opportunities for the synthesis of both homo- and heteroleptic complexes and would provide insight in the mechanism of the reaction. The first step would result in the formation of $[\mathrm{PtCl}(\mathrm{C}, \mathrm{N}) \mathrm{L}](\mathrm{L}=$ coordinating ligand), which after isolation and purification could be reacted in a second step with additional bidentate $C, N$-lithium complexes to form either a homoleptic $\left[\mathrm{Pt}(\mathrm{C}, \mathrm{N})_{2}\right]$ or heteroleptic $\left[\mathrm{Pt}\left(\mathrm{C}^{\prime}, \mathrm{N}^{\prime}\right)(\mathrm{C}, \mathrm{N})\right] \mathrm{com}-$ plex. We tested this procedure for the synthesis of $\mathbf{1 0}$. The in situ generated lithium complex $\mathbf{1 6}$ was reacted with 0.95 equiv of $\left[\mathrm{PtCl}_{2}\left(\mathrm{SEt}_{2}\right)_{2}\right]$ (cis/trans $\left.=1: 1\right)$ in $\mathrm{Et}_{2} \mathrm{O}$ (Scheme 4). The conversion to the trans-complex $\mathbf{1 7}$ was

(13) Deuschel-Cornioley, C.; Stoeckli-Evans, H.; von Zelewsky, A. J. Chem. Soc., Chem. Commun. 1990, 121-122.
Scheme 4. Synthesis of 10 in a Two-Step Procedure $^{a}$
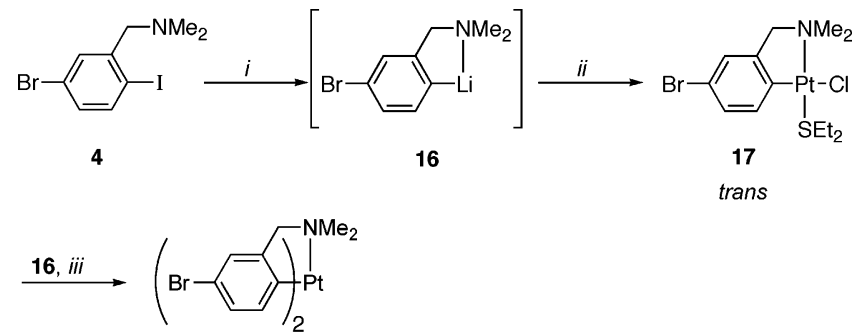

cis- and trans-10

a (i) $n$-BuLi, $\mathrm{Et}_{2} \mathrm{O},-78^{\circ} \mathrm{C}, 10 \mathrm{~min}$; (ii) $\left[\mathrm{PtCl}_{2}\left(\mathrm{SEt}_{2}\right)_{2}\right], \mathrm{Et}_{2} \mathrm{O}$, $-78{ }^{\circ} \mathrm{C} \rightarrow \mathrm{RT}, 3 \mathrm{~h}$; (iii) $\mathrm{Et}_{2} \mathrm{O}, \mathrm{O}^{\circ} \mathrm{C} \rightarrow \mathrm{RT}, 3 \mathrm{~h}$.

Table 2. Selected Bond Lengths (Å), Bond Angles (deg), and Torsion Angles (deg) for cis-12 $\cdot \mathbf{E t}_{2} \mathrm{O}$

\begin{tabular}{rccc}
\hline \multicolumn{5}{c}{ Interatomic Distances } \\
\multicolumn{1}{c}{$\mathrm{Pt}-\mathrm{C}(1)$} & $1.992(4)$ & $\mathrm{Pt}-\mathrm{C}(13)$ & $1.991(4)$ \\
$\mathrm{Pt}-\mathrm{N}(1)$ & $2.202(3)$ & $\mathrm{Pt}-\mathrm{N}(3)$ & $2.202(4)$ \\
\multicolumn{5}{c}{ Interatomic Angles and Torsion Angles } \\
$\mathrm{C}(1)-\mathrm{Pt}-\mathrm{C}(13)$ & $97.38(16)$ & $\mathrm{N}(1)-\mathrm{Pt}-\mathrm{N}(3)$ & $102.53(14)$ \\
$\mathrm{N}(1)-\mathrm{Pt}-\mathrm{C}(1)$ & $80.25(14) \mathrm{N}(3)-\mathrm{Pt}-\mathrm{C}(13)$ & $80.95(16)$ \\
$\mathrm{N}(1)-\mathrm{Pt}-\mathrm{C}(13)$ & $171.40(14)$ & $\mathrm{N}(3)-\mathrm{Pt}-\mathrm{C}(1)$ & $171.84(14)$ \\
$\mathrm{N}(1)-\mathrm{Pt}-\mathrm{C}(1)-\mathrm{C}(2)$ & $-15.4(3)$ & $\mathrm{N}(3)-\mathrm{Pt}-\mathrm{C}(13)-\mathrm{C}(14)$ & $-13.9(3)$ \\
$\mathrm{C}(1)-\mathrm{Pt}-\mathrm{C}(13)-\mathrm{C}(18)$ & $-29.3(4)$ & $\mathrm{C}(13)-\mathrm{Pt}-\mathrm{C}(1)-\mathrm{C}(6)$ & $-30.6(3)$
\end{tabular}

complete in $3 \mathrm{~h}$. On the basis of the ${ }^{3} \boldsymbol{J}_{\mathrm{Pt}-\mathrm{H}}$ coupling constants, which are consistent with other transcomplexes $\left({ }^{3} J_{\mathrm{Pt}-\mathrm{H}}=35\right.$ and $42 \mathrm{~Hz}$ for $\mathrm{NMe}_{2}$ and $\mathrm{CH}_{2} \mathrm{~N}$, respectively, see Table 4), ${ }^{2}$ complex $\mathbf{1 7}$ was assigned to be the trans-isomer with the anionic groups (aryl and chloride) positioned trans to each other. NMR analysis of the product showed the presence of $\mathbf{1 7}$ and a small amount of cis-10 (5\%), which could be removed by column chromatography. ${ }^{14}$ In the second step, pure $\mathbf{1 7}$ was reacted with $\mathbf{1 6}$ in $\mathrm{Et}_{2} \mathrm{O}$. This led to a complete conversion of $\mathbf{1 7}$ to homoleptic $\mathbf{1 0}$ in a cis/trans ratio of $80: 20$. It is interesting to note that the cis/trans ratio is in accordance with that found for the single-step procedure, thus showing that $\mathbf{1 7}$ is the intermediate in that reaction.

It should be noted that the in situ prepared lithium reagents contain either LiI (reaction of $\mathbf{5}, \mathbf{6}$, and $\mathbf{8}$ with $t$-BuLi) or $n$-BuI (reaction with $n$-BuLi) in the reaction mixtures. Workup of the reaction mixtures of 10, 11, and 13 revealed that these bisaryl platinum(II) complexes are prone to further reacting to platinum(IV) derivatives; that is, under these conditions these platinum(II) compounds undergo oxidation by reaction with electrophiles. ${ }^{15}$ For example, during the synthesis of $\mathrm{cis}$ 10, in the presence of LiI, a rapid, subsequent conversion of cis-10 to the $\mathrm{Pt}^{\mathrm{IV}}$ compound trans, cis- $\left[\mathrm{PtI}_{2}\left\{\mathrm{C}_{6} \mathrm{H}_{3}\right.\right.$ Br-4- $\left.\left.\left(\mathrm{CH}_{2} \mathrm{NMe}_{2}\right)-2\right\}_{2}\right]$ (18) was observed. ${ }^{16}$ In this complex, the bidentate ligands are in their original position,

(14) In the ${ }^{1} \mathrm{H}$ NMR spectra ${ }^{3} J_{\mathrm{Pt}-\mathrm{H}}$ couplings of 35 and $42 \mathrm{~Hz}$ were observed for the $\mathrm{NMe}_{2}$ and $\mathrm{CH}_{2}$ groups, respectively. This is in line with values found for the closely related trans-[PtCl(C,N)(DMSO)] complexes (32-34 and 39-40 Hz, respectively). (a) Meijer, M. D.; de Wolf, E.; Lutz, M. Spek, A. L.; van Klink, G. P. M.; van Koten, G. Organometallics 2001, 20, 4198-4206. (b) Kleij, A. W.; Klein Gebbink, R. J. M.; Lutz, M.; Spek, A. L.; van Koten, G. J. Organomet. Chem. 2001, 621, 190-196.

(15) (a) van Beek, J. A. M.; van Koten, G.; Wehman-Ooyevaar, I. C. M.; Smeets, W. J. J.; van der Sluis, P.; Spek, A. L. J. Chem. Soc., Dalton Trans. 1991, 883-893. (b) Wehman, E.; van Koten, G.; Knaap, C. T.; Ossor, H.; Pfeffer, M.; Spek, A. L. Inorg. Chem. 1988, 27, 4409-4417. 
Table 3. Selected Bond Lengths (Å), Bond Angles (deg), and Torsion Angles (deg) for cis-14·x $\mathbf{C}_{6} \mathbf{H}_{6}$

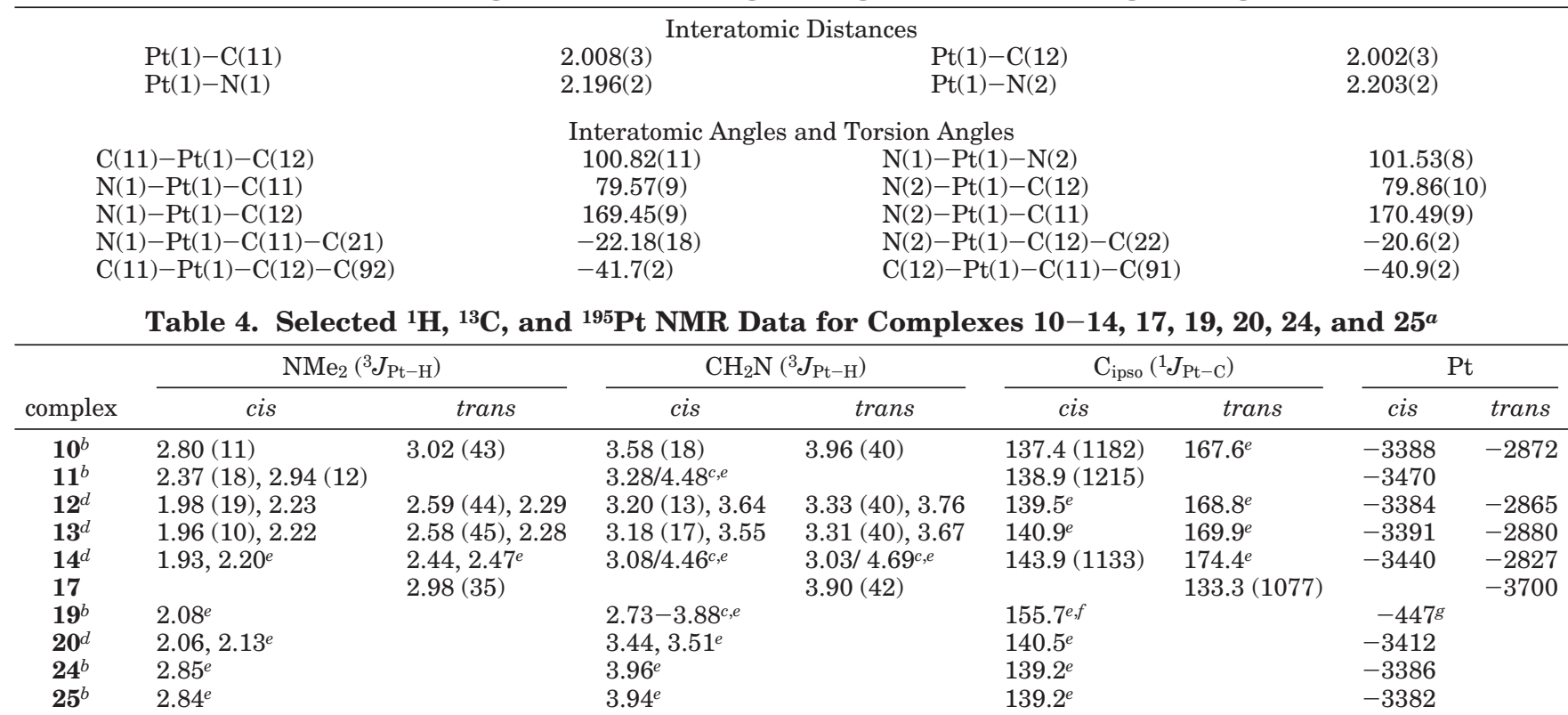

${ }^{a}$ Chemical shifts in ppm, coupling in hertz, singlet resonances unless stated otherwise, $25{ }^{\circ} \mathrm{C} .{ }^{b}$ In $\mathrm{CDCl}_{3}$ solutions. ${ }^{c} \mathrm{AX}$ pattern. ${ }^{d}$ In $\mathrm{C}_{6} \mathrm{D}_{6}$ solutions. ${ }^{e} \boldsymbol{J}_{\mathrm{Pt}-\mathrm{H}}$ or ${ }^{1} \boldsymbol{J}_{\mathrm{Pt}-\mathrm{C}}$ coupling not observed. ${ }^{f}$ Double doublet, ${ }^{2} \boldsymbol{J}_{\mathrm{P}-\mathrm{C}}=98 \mathrm{~Hz}($ trans $),{ }^{2} \boldsymbol{J}_{\mathrm{P}-\mathrm{C}}=15 \mathrm{~Hz}($ cis $) .{ }^{g}$ Doublet, ${ }^{1} \boldsymbol{J}_{\mathrm{Pt}-\mathrm{P}}=$ $1744 \mathrm{~Hz}$.

Scheme 5. Synthesis of Platinum(IV) Complex $18^{a}$

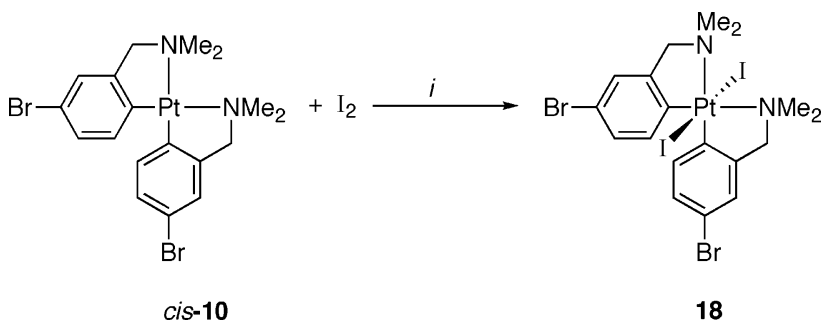

a (i) $\mathrm{CH}_{2} \mathrm{Cl}_{2}, 1 \mathrm{~h}$.

while the new iodide ligands were placed trans to each other, above and below the coordination plane. ${ }^{15 a}$ Independent synthesis of $\mathbf{1 8}$ by adding 1 equiv of $\mathrm{I}_{2}$ to a solution of cis-10 in $\mathrm{CH}_{2} \mathrm{Cl}_{2}$ afforded immediately a bright orange-colored solid (Scheme 5). This solid, which is insoluble in the greater part of the common solvents, had the correct elemental analysis based on the proposed composition for $18 .{ }^{1} \mathrm{H}$ NMR analysis was carried out on an in situ prepared solution of $\mathbf{1 8}$ in $\mathrm{CDCl}_{3}$ and confirmed the proposed structure. ${ }^{17}$

Isomerization of trans-[Pt(C,N $\left.)_{2}\right]$ Complexes. All trans-complexes of $\mathbf{1 0}$ and $\mathbf{1 2 - 1 4}$ can be isomerized quantitatively into the corresponding cis-isomers by heating a solution of cis-trans mixture to reflux for several hours in toluene. Geometrical isomerization by heating solid trans -1 for $5 \mathrm{~h}$ at $150{ }^{\circ} \mathrm{C}$, which resulted in the quantitative formation of cis-1, has already been reported. ${ }^{8}$ Complete isomerization of trans-12 and trans13 into the corresponding cis-isomers occurred within a few hours, whereas full isomerization of trans-10 and trans $\mathbf{1 4}$ needed $16 \mathrm{~h}$ of reaction time (all reactions were monitored by ${ }^{1} \mathrm{H}$ NMR analysis of samples taken from

(16) $\mathrm{I}^{-}$is in equilibrium with $\mathrm{I}_{2}$, which upon formation immediately reacts with the platinum(II) complex $\left(\mathrm{I}_{3}^{-}+2 \mathrm{e}^{-} \leftrightarrow 3 \mathrm{I}^{-}(+0.53 \mathrm{~V})\right.$ and $\mathrm{I}_{2}+2 \mathrm{e}^{-} \leftrightarrow 2 \mathrm{I}^{-}(+0.62 \mathrm{~V})$

(17) Since the isolated $\mathrm{Pt}^{\mathrm{IV}}$ complex was insoluble in common organic solvents, its ${ }^{1} \mathrm{H}$ NMR spectrum was obtained from a $\mathrm{CDCl}_{3}$ solution of the $\mathrm{Pt}^{\mathrm{II}}$ complex to which a known amount of $\mathrm{I}_{2}$ had been added. the reaction mixtures at regular intervals). All isomerization reactions were irreversible.

The reaction mechanism for trans-cis isomerization of the platinum group organometallic complexes has been the subject of considerable debate. Five-coordinate intermediates have been assumed to be involved in isomerization reactions, either catalyzed by the solvent or by addition of an extra ligand. ${ }^{18}$ For trans-cis isomerization in the absence of free ligands a dissociative pathway through three-coordinate intermediates and coordination of a solvent molecule has been proposed. ${ }^{19}$ It was found that electron-donating para and meta substituents in $\left[\mathrm{PtX}\left(\mathrm{C}_{6} \mathrm{H}_{4} \mathrm{R}\right)\left(\mathrm{PEt}_{3}\right)_{2}\right](\mathrm{R}=\mathrm{OMe}$, $\mathrm{Me}$ ) enhanced the rate of isomerization. ${ }^{19 a}$ The relatively fast isomerization of complexes $\mathbf{1 2}$ and $\mathbf{1 3}$ can be ascribed to the presence of the potentially chelating $5-\mathrm{CH}_{2} \mathrm{NMe}_{2}$ substituents. These groups can enhance the thermal isomerization reaction both due to their electrondonating properties and via intermolecular coordination in an associative pathway.

Structural Aspects of $\left[\mathrm{Pt}(\mathrm{C}, \mathrm{N})_{2}\right]$ Complexes 1014. Solid-State Structures of cis-12 and cis-14. $\boldsymbol{x} \mathbf{C}_{6} \mathbf{H}_{6}$. Slow distillation of $\mathrm{Et}_{2} \mathrm{O}$ to a saturated solution of cis-12 in $\mathrm{CH}_{2} \mathrm{Cl}_{2}$ afforded single crystals of cis-12. $\mathrm{Et}_{2} \mathrm{O}$, which were suitable for X-ray crystal structure determination. The molecular structure is depicted in Figure 1 (see Table 2 for relevant bond lengths, bond angles, and torsion angles). The structure shows that the metal center is bonded to two bidentate, $C, N$-bonded amino aryl ligands in the cis-configuration and has a slightly distorted square-planar geometry. The two meta-amino substituents are not coordinated. The distorted square-planar geometry is reflected by the acute bite angles of the two $C, N$-ligands at the platinum

(18) (a) Favez, R.; Roulet, R.; Pinkerton, A. A.; Schwarzenbach, D. Inorg. Chem. 1980, 19, 1356-1365. (b) van Eldik, R.; Palmer, D. A.; Kelm, H.; Louw, W. J. Inorg. Chem. 1980, 19, 3551-3552.

(19) (a) Romeo, R.; Minniti, D.; Lanza, S. Inorg. Chem. 1979, 18, 2362-2368. (b) Price, J. H.; Birk, J. P.; Wayland, B. B. Inorg. Chem. 1978, 17, 2245-2250. 


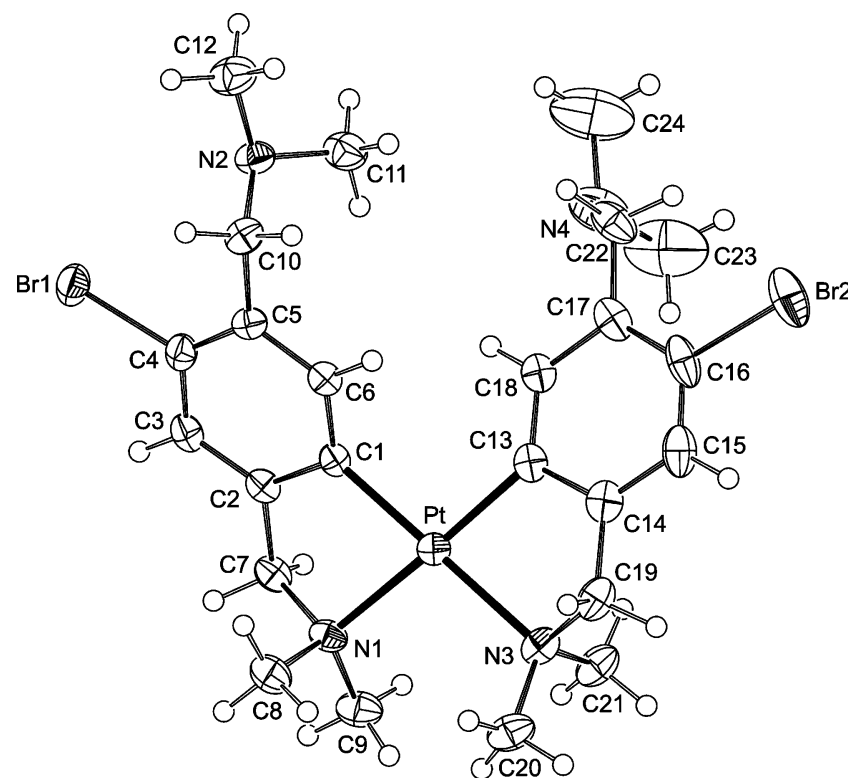

Figure 1. Displacement ellipsoid plot (50\% probability level) of the molecular structure of $c i s-\mathbf{1 2} \cdot \mathrm{Et}_{2} \mathrm{O}$, with the adopted labeling scheme. The $\mathrm{Et}_{2} \mathrm{O}$ solvent molecule has been omitted for clarity.

center, 80.25(14) $)^{\circ}(\mathrm{N}(1)-\mathrm{Pt}-\mathrm{C}(1))$ and $80.95(16)^{\circ}(\mathrm{N}(3)-$ $\mathrm{Pt}-\mathrm{C}(13))$. The two five-membered metallacycles are puckered, which is shown by angles between the platinum coordination plane and the aryl plane of $-15.4(3)^{\circ}$ and $-13.9(3)^{\circ}(\mathrm{N}(1)-\mathrm{Pt}-\mathrm{C}(1)-\mathrm{C}(2)$ and $\mathrm{N}(3)-\mathrm{Pt}-\mathrm{C}(13)-$ $\mathrm{C}(14)$, respectively). The $\mathrm{C}-\mathrm{Pt}$ and $\mathrm{N}-\mathrm{Pt}$ bond lengths fall in the range of other platinum(II) complexes with chelate-bonded $C, N$-ligands $(\mathrm{C}-\mathrm{Pt}$ : $2.000-2.025 \AA$, N-Pt: $2.139-2.164 \AA) .13,14,20,21$

Crystals of cis-14. $x \mathrm{C}_{6} \mathrm{H}_{6}$ suitable for single $\mathrm{X}$-ray crystal structure determination were obtained from a saturated solution of cis-14 in benzene/pentane (9:1). The molecular structure of cis-14 (Figure 2) reveals a platinum(II) center that is ligated by two bidentate $C, N$ bonded amino naphthyl ligands in a cis-fashion, with
$\mathrm{C}-\mathrm{Pt}$ and $\mathrm{N}-\mathrm{Pt}$ bond lengths that are comparable to those of cis-12 (Table 3). The mutual steric intramolecular interference of the hydrogen atoms on $\mathrm{C}(81)$ and $\mathrm{C}(82)(\mathrm{H}(81) \cdots \mathrm{H}(82)=3.33 \AA)$ causes the ligands to distort in a unilateral anti-twist fashion. As the crystal is centrosymmetric, both $\Delta$ and $\Lambda$ enantiomers are present in a 1:1 ratio (Figure 3 ). The torsion angles of

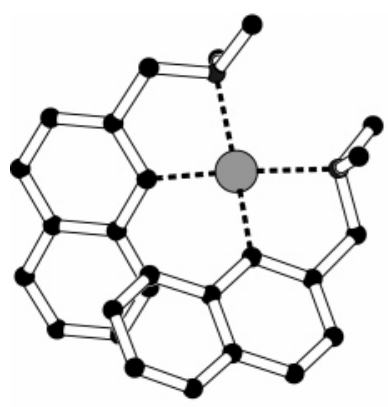

$\Lambda$

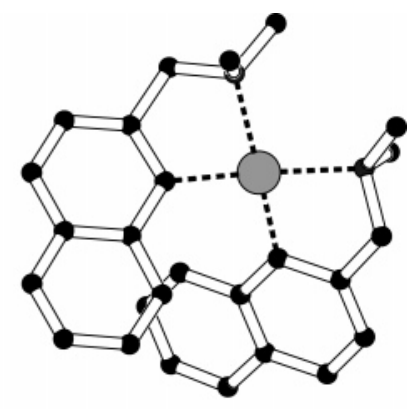

$\Delta$
Figure 3. PLUTON plot of the two enantiomers of racemic cis-14. $x \mathrm{C}_{6} \mathrm{H}_{6}, \Lambda$, left-handed helicity, and $\Delta$, right-handed helicity.

the platinum coordination plane with the aryl plane are considerably larger than for cis-12, -41.7(2) ${ }^{\circ}$ and -40.9(2) ${ }^{\circ}$ for $\mathrm{C}(11)-\mathrm{Pt}-\mathrm{C}(12)-\mathrm{C}(92)$ and $\mathrm{C}(12)-\mathrm{Pt}-\mathrm{C}(11)-$ C(91), respectively. Similar values for these torsion angles were found for related planar chiral palladium(II) and platinum(II) complexes $\left(38.3-44.5^{\circ}\right) .{ }^{12,22}$ The $\mathrm{C}-\mathrm{Pt}-\mathrm{N}$ bite angles $\left(79.57(9)^{\circ}\right.$ and $79.86(10)^{\circ}$ for $\mathrm{N}(1)-$ $\mathrm{Pt}-\mathrm{C}(11)$ and $\mathrm{N}(2)-\mathrm{Pt}-\mathrm{C}(12)$, respectively) are similar to those of cis-12 and are in the range of angles found for related homo- and heteroleptic $\left[\mathrm{M}\left(\eta^{2}-\mathrm{C}, \mathrm{N}\right)\right](\mathrm{M}=\mathrm{Pt}$, $\mathrm{Pd})$ complexes $\left(78.5-80.9^{\circ}\right){ }^{13,22,23}$

NMR Analysis of Complexes 10-14. Complexes 11 and 14 showed two singlet signals for the dimethylamino protons and an AX pattern for the benzylic protons for cis-11, cis-14, and trans-14 (Table 4). The

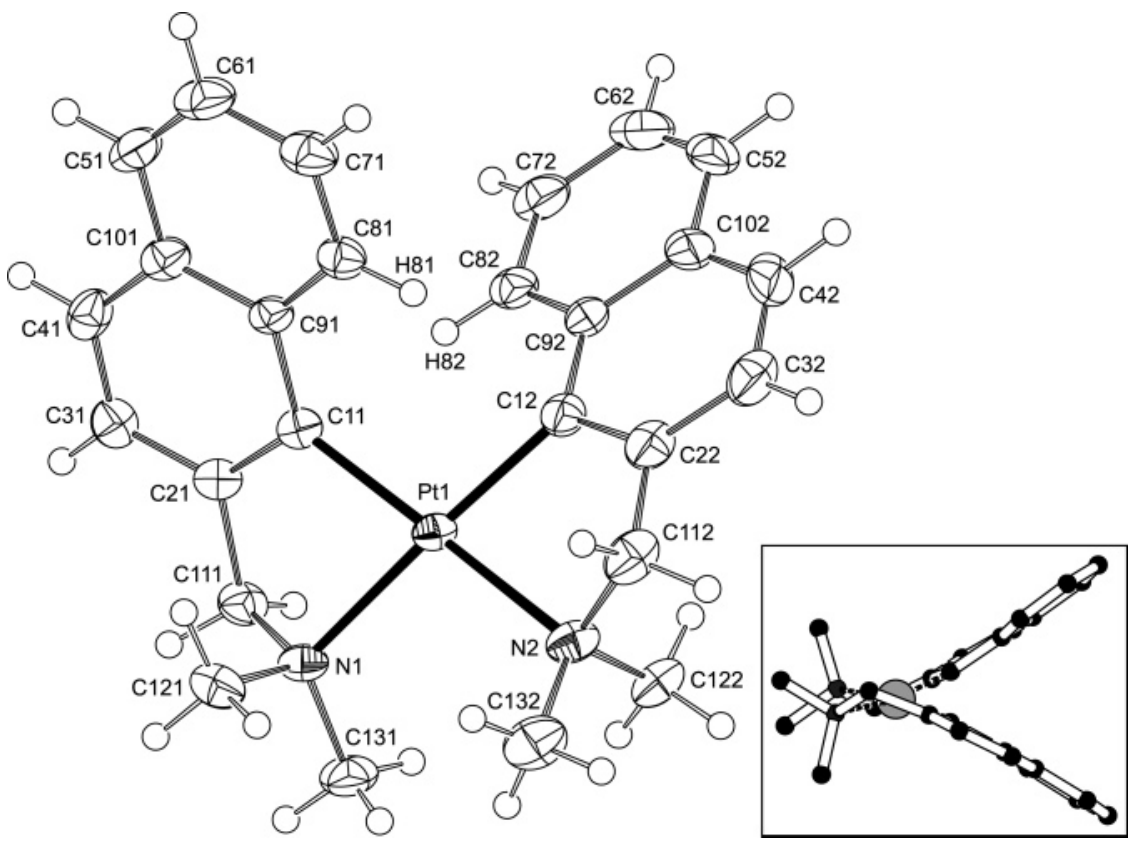

Figure 2. Displacement ellipsoid plot (50\% probability level) of the molecular structure of $c i s-14 \cdot x \mathrm{C}_{6} \mathrm{H}_{6}$, with the adopted labeling scheme. Disordered solvent molecules are not shown. The inset shows a side view of $\operatorname{cis}-\mathbf{1 4} \cdot x \mathrm{C}_{6} \mathrm{H}_{6}$. 
resonances of trans-14 have distinct downfield shifts with respect to those of cis-14. The presence of AX patterns indicates that under these conditions there is no apparent molecular symmetry plane containing the benzylic carbon and nitrogen centers. This arises from the asymmetric environment that is created by the presence of steric bulk, which prevents a twist of the arene rings with respect to each other and thus induces planar chirality. The asymmetric environment was already observed for $\mathbf{1 4}$ in solid state. Both cis- and trans-isomers have a $C_{2}$ symmetry in solution. Variabletemperature ${ }^{1} \mathrm{H}$ NMR experiments of $\mathbf{1 1}$ and cis-14 from -95 to $+95{ }^{\circ} \mathrm{C}$ in toluene- $d_{8}$ did not reveal changes in the spectra. Interconversion of the two diastereoisomers, $\Delta$ and $\Lambda$, is not observed on the NMR time scale.

Singlet signals for the methyl protons and benzylic protons of the coordinated methylene amino substituents of the cis- and trans-isomers of 10, 12, and 13 were observed. Similar downfield shifts of the signals for the trans-compounds with respect to the corresponding cisisomers were observed $(\Delta \delta(\mathrm{H})=0.13-0.64 \mathrm{ppm}$, Table 4). The benzylic protons showed the ${ }^{3} J_{\mathrm{Pt}-\mathrm{H}}$ coupling constants of 18 (cis) and 40 (trans) $\mathrm{Hz}$, while the methyl signals displayed coupling constants of 11 and $44 \mathrm{~Hz}$ for the cis- and trans-isomers, respectively. These differences point to a different $\mathrm{Pt}-\mathrm{N}$ bond strength, as a result of the different trans-ligands, either aryl (cis) or amine (trans). In the trans-complexes, the trans-influence is weaker, giving rise to larger platinum couplings. ${ }^{2}$ The cis-complexes have $C_{2 v}$ symmetry, whereas the trans-complexes exert a $C_{2 h}$ symmetry.

Variable-temperature ${ }^{1} \mathrm{H}$ NMR experiments were carried out to study the dynamic aspects of the cisisomers. Low-temperature ${ }^{1} \mathrm{H}$ NMR spectra were recorded in $\mathrm{CD}_{2} \mathrm{Cl}_{2}$. Lowering the temperature resulted in broadening of the proton resonances of the $\mathrm{CH}_{2} \mathrm{NMe}_{2}$ groups coordinated to the platinum center. For complexes cis-12 and cis-13, the $\mathrm{NMe}_{2}$ and $\mathrm{CH}_{2} \mathrm{~N}$ singlet signals decoalesced into two broad singlets at $-93{ }^{\circ} \mathrm{C}$ $\left(\Delta G^{\ddagger}=35 \mathrm{~kJ} \cdot \mathrm{mol}^{-1}\right){ }^{24}$ The decoalescence of these resonances for cis-10 was not observed at temperatures down to $-110{ }^{\circ} \mathrm{C}$. This indicates that for cis-12 and cis$\mathbf{1 3}$ at low temperatures the interconversion process between the two diastereoisomers $\Delta$ and $\Lambda$ is sufficiently slow. In contrast, this process is not observed for cis-10 at low temperatures. This is probably caused by the absence of meta-substituents, whose steric interference can hamper twisting of the arene rings.

Ligand Displacement. Previous reports have shown that the hard donor amine ligands in cyclometalated aminoaryl platinum complexes can be replaced by phosphine ligands, as the soft platinum center favors coordination to the softer phosphine ligands..$^{3,25,26}$ In our

(20) Meijer, M. D.; Kleij, A. W.; Williams, B. S.; Ellis, D. D.; Lutz, M.; Spek, A. L.; van Klink, G. P. M.; van Koten, G. Organometallics 2002, 21, 264-271.

(21) Amijs, C. H. M.; Berger, A.; van Klink, G. P. M.; Lutz, M.; Spek, A. L.; van Koten, G. Manuscript in preparation.

(22) Valk, J.-M. Ph.D. Thesis, Utrecht University, The Netherlands, 1993.

(23) (a) Janecki, T.; Jeffreys, J. A. D.; Pauson, P. L.; Pietrzykowski, A. Organometallics 1987, 6, 1553-1560. (b) Fuchita, Y.; Yoshinaga, K.; Hanaki, T.; Kawano, H.; Kinoshita-Nagaoka, J. J. Organomet. Chem. 1999, 580, 273-281.

(24) Calculated with formula $\left.\Delta G^{\ddagger}=R T_{\mathrm{c}} \ln \left\{(\sqrt{ } 2) k_{\mathrm{b}} T_{\mathrm{c}}\right) / h \pi(\Delta v)\right\}$ from: Drago, R. S. Physical Methods in Inorganic Chemistry; Reinhold Publishing Corporation: New York, 1965.
Scheme 6. Reaction of cis-10 with dppp ${ }^{a}$

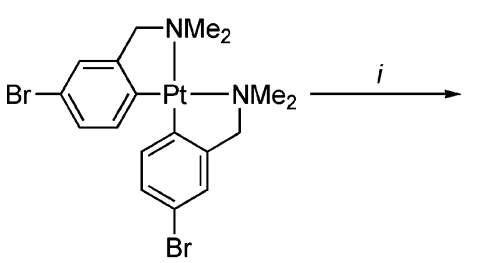

cis-10

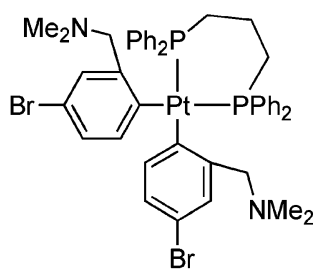

19

\footnotetext{
a (i) dppp, $\mathrm{CH}_{2} \mathrm{Cl}_{2}, \mathrm{RT}, 5$ min.
}

case a partial ligand displacement, i.e., substitution of the chelating amine groups, should result in the formation of monodentate $\eta^{1}$-C-bonded aminoaryl ligands with a dangling $\mathrm{CH}_{2} \mathrm{NMe}_{2}$ base functionality. Reaction of cis10 with 1 equiv of the bidentate 1,3-(diphenylphosphino)propane (dppp) ligand in $\mathrm{CH}_{2} \mathrm{Cl}_{2}$ resulted in the rapid conversion to cis- $\left[\mathrm{Pt}\left(\eta^{1}-\mathrm{C}_{6} \mathrm{H}_{3}\left(\mathrm{CH}_{2} \mathrm{NMe}_{2}\right)-2-\mathrm{Br}-4\right)_{2}\left(\eta^{2}\right.\right.$ dppp)] (19), which contains a chelate-bonded dppp ligand (Scheme 6). The results of ${ }^{1} \mathrm{H}$ and ${ }^{31} \mathrm{P}$ NMR analysis of a solution of $\mathbf{1 9}$ excluded the possibility that the dppp ligand was either $\eta^{1}-P$ monodentate or $\mu^{2}-\eta^{2}$ $P, P^{\prime}$ bridge bonded. To study whether the dppp ligand could induce trans-to-cis isomerization, the synthesis of $\mathbf{1 9}$ was attempted starting from a cis / trans-10 isomeric mixture. Mixing of 1 equiv of dppp with 1 equiv of a 1:1 molar mixture of pure cis-10 and trans-10 isomers in $\mathrm{CDCl}_{3}$ at room temperature for 7 days did not result in complete conversion to 19. Although the cis / trans ratio was increased to $3: 1$ (75\% of cis-complex 19, $25 \%$ of trans-complex $\left.\left[\mathrm{Pt}\left(\eta^{1}-\mathrm{C}, \mathrm{N}\right)\left(\eta^{2}-\mathrm{C}, \mathrm{N}\right)\left(\eta^{1}-\mathrm{dppp}\right)\right]\right)$, indicating that $50 \%$ trans-to-cis isomerization was achieved, the presence of dppp did not enhance the isomerization reaction to a great extent.

Structural Aspects of [Pt $\left(\eta^{1}-\mathbf{C}, \mathbf{N}\right)_{2}\left(\eta^{2}\right.$-dppp)] (19). Solid-State Structure. Single crystals of 19 were obtained by cooling a saturated solution of 19 in $\mathrm{CH}_{2}$ $\mathrm{Cl}_{2}$ at $4{ }^{\circ} \mathrm{C}$. A molecular plot of the molecular structure is depicted in Figure 4, while Table 5 shows a selection of bond lengths, bond angles, and torsion angles. The structure has an exact, crystallographic $C_{2}$ symmetry. The molecular structure shows a square-planar platinum(II) complex, which possesses two monodentate $\eta^{1}$ $C$-bonded $C, N$-ligands in cis-configuration and an $\eta^{2}$ $P, P^{\prime}$-bidentate-bonded dppp ligand. The $C, N$-aryl planes are oriented perpendicular to the coordination plane of the platinum center, which contrasts with the almost coplanar situation in, for example, cis-12. The $\mathrm{Pt}-\mathrm{C}(1)$ bond is slightly elongated from $1.992(4) \AA$ in cis-12 to 2.065(4) $\AA$ in 19. The noncoordinating ortho-amino groups are directed away from the metal center, in an $E$-conformation. ${ }^{27}$ Only the $E$-stereoisomer is present in the crystal, whereas a mixture of $E$ - and $Z$-conformers is present in solution. The $\mathrm{P}(1)-\mathrm{Pt}-\mathrm{P}(1)^{\mathrm{i}}$ bite angle $\left(89.69(6)^{\circ}\right)$ has a lower value than the $\mathrm{P}-\mathrm{Pt}-\mathrm{P}$ bite angles observed in related complexes $\left(94.63-97.02(8)^{\circ}\right)$,

(25) Zucca, A.; Stoccoro, S.; Cinellu, M. A.; Minghetti, G.; Manassero, M.; Sansoni, M. Eur. J. Inorg. Chem. 2002, 3336-3346.

(26) (a) Albrecht, M.; Dani, P.; Lutz, M.; Spek, A. L.; van Koten, G J. Am. Chem. Soc. 2000, 122, 11822-11833. (b) van Koten, G.; Timmer K.; Noltes, J. G.; Spek, A. L. J. Chem. Soc., Chem. Commun. 1978, $250-252$.

(27) Baumgärtner, R.; Schmidtberg, G.; Brune, H.-A. J. Organomet Chem. 1988, 345, 221-232. 


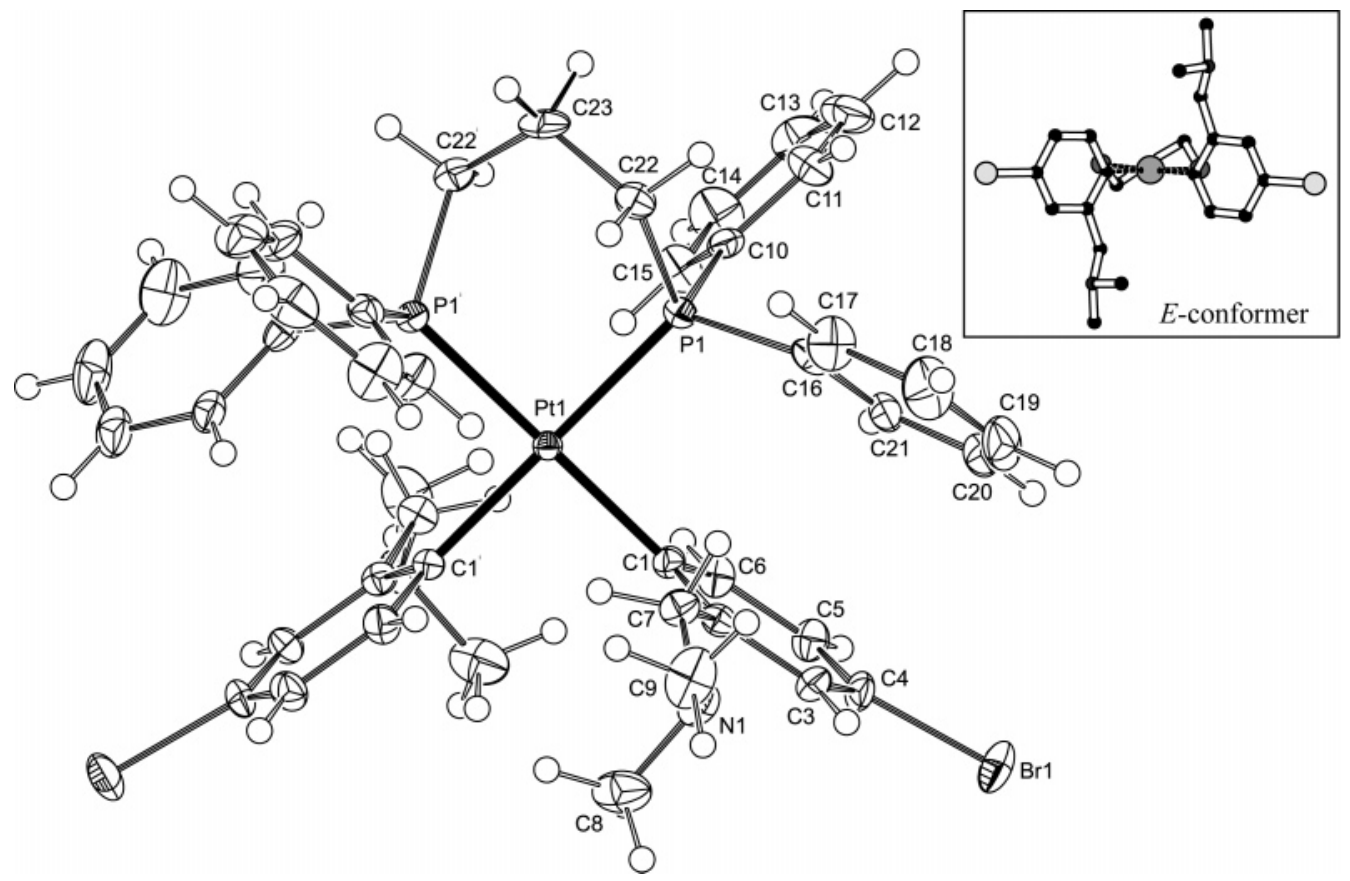

Figure 4. Displacement ellipsoid plot (50\% probability level) of the molecular structure of 19, with the adopted labeling scheme. Disordered solvent molecules have been omitted for clarity. Symmetry operation i: $1-x, y, 0.5-z$. The inset shows a view along the 2 -fold axis of $\mathbf{1 9}$ with the $E$-conformation.

Table 5. Selected Bond Lengths (Å), Bond Angles (deg), and Torsion Angles (deg) for 19

\begin{tabular}{cccc}
\hline \multicolumn{5}{c}{ Interatomic Distances } \\
$\mathrm{Pt}(1)-\mathrm{C}(1)$ & $2.065(4)$ & $\mathrm{Pt}(1)-\mathrm{P}(1)$ & $2.2998(11)$ \\
$\mathrm{P}(1)-\mathrm{C}(10)$ & $1.829(5)$ & $\mathrm{P}(1)-\mathrm{C}(16)$ & $1.828(5)$ \\
$\mathrm{P}(1)-\mathrm{C}(22)$ & $1.833(5)$ & & \\
\multicolumn{5}{c}{ Interatomic Angles and Torsion Angles } \\
$\mathrm{C}(1)-\mathrm{Pt}(1)-\mathrm{C}(1)^{\mathrm{i}}$ & $89.7(2)$ & $\mathrm{P}(1)-\mathrm{Pt}(1)-\mathrm{P}(1)^{\mathrm{i}}$ & $89.69(6)$ \\
$\mathrm{P}(1)-\mathrm{Pt}(1)-\mathrm{C}(1)$ & $90.34(12)$ & $\mathrm{P}(1)-\mathrm{Pt}(1)-\mathrm{C}(1)^{\mathrm{i}}$ & $179.00(13)$ \\
$\mathrm{P}(1)-\mathrm{Pt}(1)-\mathrm{C}(1)-\mathrm{C}(2)$ & $85.8(3)$ & $\mathrm{C}(1)^{\mathrm{i}}-\mathrm{Pt}(1)-\mathrm{C}(1)-\mathrm{C}(2)$ & $-95.2(4)$
\end{tabular}

while the $\mathrm{Pt}-\mathrm{P}$ distance $(2.2998(11) \AA$ ) lies within the range found for these complexes $(2.271-2.305 \AA) .28$

Structure in Solution. The ${ }^{1} \mathrm{H}$ NMR spectrum of 19 in $\mathrm{CD}_{2} \mathrm{Cl}_{2}$ reveals an $\mathrm{AX}$ pattern for the benzylic protons with platinum couplings. This shows that $\mathbf{1 9}$ lacks a symmetry plane containing the benzylic carbon atoms. ${ }^{31} \mathrm{P}$ and ${ }^{195} \mathrm{Pt} \mathrm{NMR}$ analysis showed that the cisconfiguration is retained. The coupling constant ${ }^{1} J_{\mathrm{Pt}-\mathrm{P}}$ is $1721 \mathrm{~Hz}$, which is in accordance with values found for related cis-complexes $(1669-1748 \mathrm{~Hz}){ }^{29}$ The presence of one sharp phosphor signal at $-4.46 \mathrm{ppm}$ points to one single complex in solution, i.e., a complex with an intramolecularly coordinated dppp ligand. The NMR spectra did not reveal the presence of the two $E$ - and $Z$-conformers. Most likely, this indicates that the barrier for rotation of the aryl rings about the $\mathrm{Pt}-\mathrm{C}_{\mathrm{ipso}}$ axis is very low, and therefore fast interchange between the two conformers on the NMR time scale occurs. The alternate possibility, i.e., a high rotation barrier for the $E-Z$ interconversion process, can be excluded because this would lead to two resonance patterns, one for the $E$ - and one for the $Z$-conformer, whereas one resonance pattern is observed over a wide temperature range $(-85$

(28) (a) Thomas, J. C.; Peters, J. C. J. Am. Chem. Soc. 2003, 125, 8870-8888. (b) Bruce, M. I.; Costuas, K.; Halet, J.-F.; Hall, B. C.; Low, P. J.; Nicholson, B. K.; Skelton, B. W.; White, A. H. J. Chem. Soc., Dalton Trans. 2002, 383-398.

(29) Braterman, P. S.; Cross, R. J.; Young, G. B. J. Chem. Soc., Dalton Trans. 1977, 1892-1897. to $+50{ }^{\circ} \mathrm{C}$ in $\mathrm{CD}_{2} \mathrm{Cl}_{2}$ ). Apparently, the presence of the ortho- $\mathrm{CH}_{2} \mathrm{NMe}_{2}$ substituents does not cause enough steric interference for the rotation or wagging process to become slow on the NMR time scale.

Functionalization of $\left[\operatorname{Pt}(\mathrm{C}, \mathrm{N})_{2}\right]$ Complexes. As mentioned above, the $\left[\mathrm{Pt}(\mathrm{C}, \mathrm{N})_{2}\right]$ complexes were designed as such that they would allow further functionalization, for example by displacement of the chelate-bonded amine ligands by addition of a stronger coordinating phosphine ligand (vide supra). Furthermore, the halide groups at the aryl rings can be used for substitution reactions, via either lithiation or metal-catalyzed $\mathrm{C}-\mathrm{C}$ bond formation reactions. These kinds of nucleophilic substitution reactions are rarely performed on organometallic complexes, and only a few examples have been reported. ${ }^{30,31}$ We have performed two types of functionalization reactions with the cis-isomers of $\mathbf{1 0}$ and $\mathbf{1 2}$, i.e., lithiation and subsequent transmetalation reactions and $\mathrm{C}-\mathrm{C}$ coupling reactions.

Lithiation and Transmetalation Reactions. Lithiation of the bromide substituents of cis-10 and cis-12, respectively, was carried out by reaction with either $n$ or $t$-BuLi, followed by quenching the in situ prepared 4,4'-bis(lithio-aryl) platinum complex with [ $\left.\mathrm{SnBrMe}_{3}\right]$. Double lithiation and subsequent transmetalation of cis12 was possible by adding 4 equiv of $n$-BuLi to a solution of cis-12 in THF at $0{ }^{\circ} \mathrm{C}$ (Scheme 7)..$^{32}$ The bisstannane product 20 was purified by column chromatography.

(30) Lithiation reactions: (a) Ref 3. (b) Clark, A. M.; Richard, C. E. F.; Roper, W. R.; Wright, L. J. Organometallics 1998, 17, 4535-4537. (c) Clark, A. M.; Richard, C. E. F.; Roper, W. R.; Wright, L. J. Organometallics 1999, 18, 2813-2820. (d) Slagt, M. Q.; Klein Gebbink, R. J. M.; Lutz, M.; Spek, A. L.; van Koten, G. J. Chem. Soc., Dalton Trans. 2002, 2591-2592.

(31) C-C coupling reactions: (a) Lau, M.-K.; Zhang, Q.-F.; Chim, J. L C.; Wong, W.-T.; Leung, W.-H. Chem. Commun. 2001, 1478-1479. (b) Fraysse, S.; Coudret, C.; Launay, J.-P. J. Am. Chem. Soc. 2003, 125, 5880-5888. (c) Chodorowski-Kimmes, S.; Beley, M.; Collin, J.-P.; Sauvage, J.-P. Tetrahedron Lett. 1996, 37, 2963-2966. 
Scheme 7. Lithiation and Transmetalation Reaction with cis-12 ${ }^{a}$

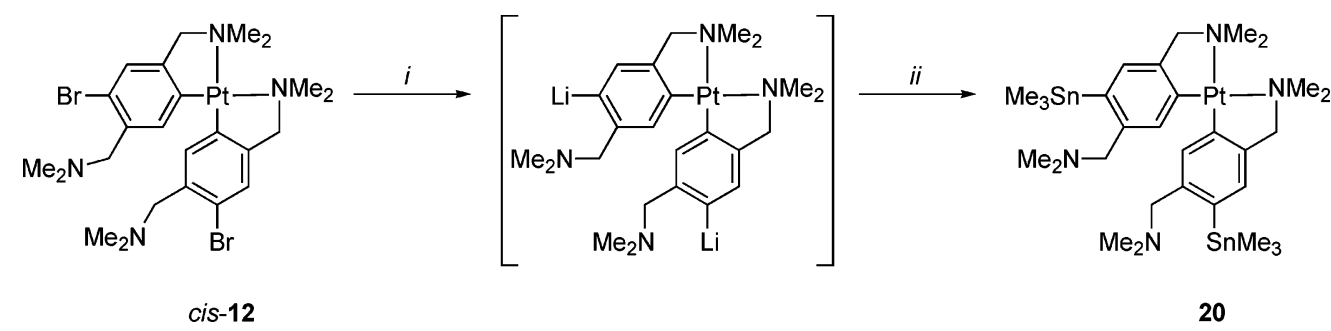

a (i) $n$-BuLi, THF, $0{ }^{\circ} \mathrm{C}, 15 \mathrm{~min}$; (ii) $\left[\mathrm{SnBrMe}_{3}\right], \mathrm{THF}, 0^{\circ} \mathrm{C} \rightarrow \mathrm{RT}, 1 \mathrm{~h}$.

Selective double lithiation of cis-10 at the bromide position could not be achieved. Using either $n$-BuLi or $t$-BuLi in THF at low temperatures $\left(<-80^{\circ} \mathrm{C}, 15 \mathrm{~min}\right.$ to $1 \mathrm{~h}$ ) did not result in the required lithiation. Each time, unchanged cis-10 was recovered after the lithiation reaction and it could even be reused after purification. At higher temperatures in THF $\left(>-30^{\circ} \mathrm{C}, 5 \mathrm{~min}\right.$ to $1 \mathrm{~h}$ ), mixtures of products were obtained from the reaction of cis-10 with $n$-BuLi and subsequent quenching with $\left[\mathrm{SnBrMe}_{3}\right]$. Next to some nonreacted cis-10, some transmetalated complexes and significant amounts of $n$-butyl-functionalized complexes were obtained. As each complex can react at the 4 - and $4^{\prime}$-bromide positions, a variety of products can be expected to form, for example, $\left[\mathrm{Pt}\left(\mathrm{C}, \mathrm{N}-4-\left\{\mathrm{SnMe}_{3}\right\}\right)(\mathrm{C}, \mathrm{N}-4-\{n-\mathrm{Bu}\})\right],[\mathrm{Pt}(\mathrm{C}, \mathrm{N}-$ $\left.\left.4-\left\{\mathrm{SnMe}_{3}\right\}\right)_{2}\right],[\mathrm{Pt}(\mathrm{C}, \mathrm{N}-4-\mathrm{Br})(\mathrm{C}, \mathrm{N}-4-\{n-\mathrm{Bu}\})]$, etc. Separation of these complexes was not possible. The ratios of these products were dependent on the applied reaction conditions; higher temperatures or longer reaction times resulted in higher conversions to transmetalated and $n$-butyl-functionalized complexes. The $n$-butyl-functionalized complexes are formed in a cross-coupling reaction of the lithiated complex and in situ generated 1-bromobutane. ${ }^{30 a}$ Activation of the bromide position of $c i s-\mathbf{1 0}$ was also attempted by reaction with $[i-\mathrm{PrMgCl}]$ according to recently reported procedures by Knochel et al. ${ }^{33}$ Surprisingly, upon using 8 equiv of $[i-\mathrm{PrMgCl}]$ in $\mathrm{THF}$ at temperatures from 0 to $40{ }^{\circ} \mathrm{C}(3 \mathrm{~h})$, no reaction was observed.

The fact that full lithiation of cis-10 appeared to be impossible is in contrast to the results obtained with cis-12 and the previously reported terdentate $N, C, N$ chelating aminoaryl $\mathrm{Pt}^{\mathrm{II}}$ complexes $\left[\mathrm{PtX}\left\{\mathrm{C}_{6} \mathrm{H}_{2} \mathrm{I}-4-\mathrm{CH}_{2}-\right.\right.$ $\left.\left.\left.\mathrm{NMe}_{2}\right)_{2}-2,6\right\}\right](\mathrm{X}=\mathrm{Br}, \mathrm{I})$. The latter complexes smoothly lithiated at the iodo position para to the platinum center, by reaction with 2 equiv of $t$-BuLi in THF at $-100{ }^{\circ} \mathrm{C} .3,26$ The potentially chelating amino groups in cis-12 stabilize the formed lithium species, which prevents further reaction with the $n$-bromobutane present in the reaction mixture.

C-C Coupling and Palladation Reactions. The presence of the halide functionalities should, next to lithiation, also enable the attachment of new groups via metal-catalyzed $\mathrm{C}-\mathrm{C}$ coupling reactions. To test this possibility, a Suzuki-Miyaura coupling reaction between cis-10 and a boronic acid was performed. For this reaction, a para-functionalized SCS-pincer ligand was

(32) Four equivalents of $n$-BuLi were used to enhance solubility of the lithiated complex, see: Kronenburg, C. M. P.; Rijnberg, E. Jastrzebski, J. T. B. H.; Kooijman, H.; Spek, A. L.; van Koten, G. Eur. J. Org. Chem. 2004, 153-159.

(33) Knochel, P.; Dohle, W.; Gommermann, N.; Kneisel, F. F.; Kopp, F.; Korn, T.; Sapountzis, I.; Anh Vu, V. Angew. Chem., Int. Ed. 2003 $42,4302-4320$. used, because of its usefulness for further metalation reactions. The SCS-pincer ligand $\left(\mathrm{SCS}=\left[\mathrm{C}_{6} \mathrm{H}_{3}\left(\mathrm{CH}_{2}-\right.\right.\right.$ $\left.\mathrm{SR})_{2}-2,6\right]-, \mathrm{R}=\mathrm{Ph}, \mathrm{Bu}$, etc.) is well known to easily undergo cyclopalladation. Moreover, its cationic palladium complexes have a versatile coordination chemistry with Lewis bases. ${ }^{34}$ The $c i s-\left[\mathrm{Pt}(\mathrm{C}, \mathrm{N})_{2}\right]$ complexes functionalized with SCS-Pd pincers could therefore be used as multimetallic building blocks in coordination chemistry for the construction of supramolecular assemblies.

The reagent for the $\mathrm{C}-\mathrm{C}$ coupling reaction, the pinacol-protected boronic acid of the SCS-pincer, was prepared starting from 3,5-bis(bromomethyl)bromobenzene (21, Scheme 8). Nucleophilic displacement of the benzylic bromides in 21, employing $t$-BuSNa in ethanolic solution, yielded 22 in high yield. ${ }^{34 a}$ Compound 22 was reacted in a one-pot synthesis with 2 equiv of $t$-BuLi in $\mathrm{Et}_{2} \mathrm{O}$ at $-78{ }^{\circ} \mathrm{C}$ and $\mathrm{B}(\mathrm{OMe})_{3}$, and pinacol to form 23. This compound is well soluble in organic solvents and contrary to most boronic acids $\left(\mathrm{RB}(\mathrm{OH})_{2}\right)$ insoluble in water. The pinacol-protected boronic acid 23 was reacted with cis-10 under Suzuki coupling reaction conditions at $70{ }^{\circ} \mathrm{C}$, without affecting the $\mathrm{C}-\mathrm{Pt}$ bonds in the complex. The reaction was complete within $3 \mathrm{~h}$. It is noteworthy that no decomposition of cis-10 was observed and that conversion to the cis-complex $\mathbf{2 4}$ was quantitative. Purification by column chromatography afforded $\mathbf{2 4}$ in moderate yield as an air- and moisturestable, white solid.

The commonly applied method for cyclopalladation of SCS-pincer ligands is by reaction with $\left[\mathrm{Pd}(\mathrm{NCMe})_{4}\right]-$ $\left(\mathrm{BF}_{4}\right)_{2} \cdot{ }^{34}$ Indeed, complex 24 could be cyclopalladated twice by reaction with $\left[\mathrm{Pd}(\mathrm{NCMe})_{4}\right]\left(\mathrm{BF}_{4}\right)_{2}$ in the presence of $\mathrm{NEt}_{3}$, following the method reported by Swager and co-workers. ${ }^{35}$ The in situ formed dicationic bisacetonitrile complex, which contains two noncoordinating $\left[\mathrm{BF}_{4}\right]^{-}$counteranions, was reacted with $\mathrm{NaCl}$ to form the neutral cis-complex 25. This air- and moisture-stable complex was purified by slow distillation of $\mathrm{Et}_{2} \mathrm{O}$ to a saturated solution of 25 in $\mathrm{CH}_{2} \mathrm{Cl}_{2}$.

Full conversion to the bis-SCS-functionalized complex $\mathbf{2 4}$ and its cyclopalladated derivative $\mathbf{2 5}$ was confirmed by MALDI-TOF mass analysis. The positive MALDITOF spectrum of $\mathbf{2 4}$ showed a signal corresponding to $[\mathrm{M}+\mathrm{H}]^{+}(\mathrm{m} / \mathrm{z}=1024.9)$, while the spectrum of $\mathbf{2 5}$ showed a signal corresponding to $[\mathrm{M}-\mathrm{Cl}]^{+}(\mathrm{m} / \mathrm{z}=$ 1270.7).

(34) (a) Hall, J. R.; Loeb, S. J.; Shimizu, G. K. H.; Yap, G. P. A. Angew. Chem., Int. Ed. 1998, 37, 121-123. (b) van Manen, H.-J.; Nakashima, K.; Shinkai, S.; Kooijman, H.; Spek, A. L.; van Veggel, F. C. J. M.; Reinhoudt, D. N. Eur. J. Inorg. Chem. 2000, 2533-2540. 273 
Scheme 8. Synthesis of SCS-Functionalized Corner Complexes 24 and 25 via Suzuki-Miyaura Coupling ${ }^{a}$

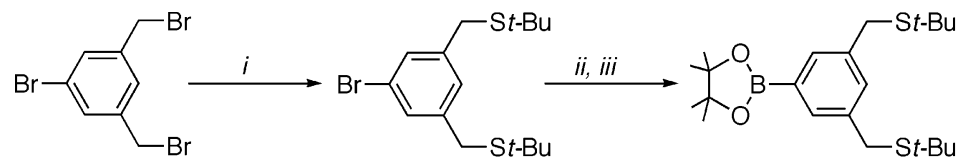

21

22

23
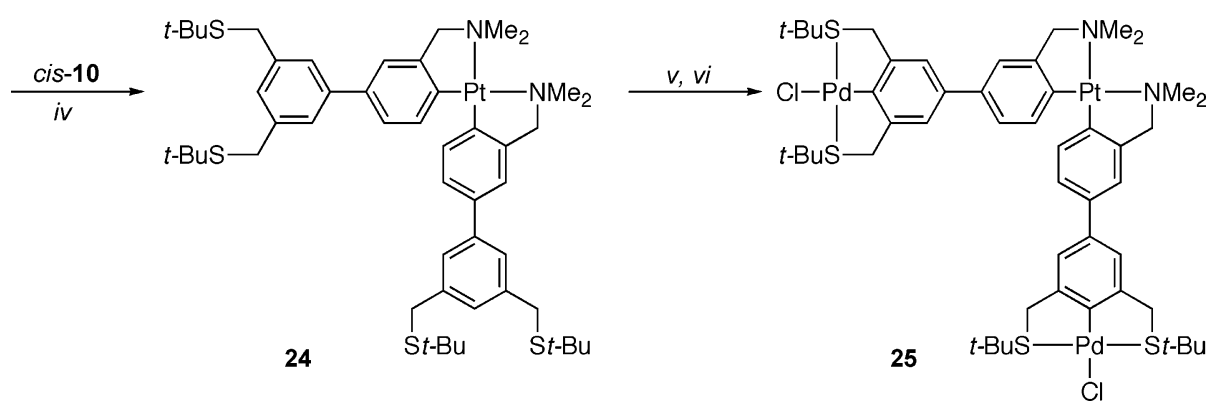

${ }^{a}$ (i) $t$-BuSNa, EtOH, $\Delta T$; (ii) 2 equiv $t$-BuLi, $\mathrm{Et} \mathrm{t}_{2} \mathrm{O},-78{ }^{\circ} \mathrm{C}, 10 \mathrm{~min}, \mathrm{~B}(\mathrm{OMe})_{3},-78{ }^{\circ} \mathrm{C} \rightarrow \mathrm{RT}, 16 \mathrm{~h}$; (iii) pinacol, $\mathrm{HOAc}, 1 \mathrm{~h}$; (iv) thf/dme/ $\mathrm{H}_{2} \mathrm{O}(1: 1: 1),\left[\mathrm{PdCl}_{2}(\mathrm{dppf})\right], \mathrm{Na}_{2} \mathrm{CO}_{3}, 70{ }^{\circ} \mathrm{C}, 3 \mathrm{~h} ;(v) 2$ equiv $\left[\mathrm{Pd}(\mathrm{NCMe})_{4}\right]\left(\mathrm{BF}_{4}\right)_{2}, \mathrm{NEt}_{3}, \mathrm{MeCN}, \Delta T, 2 \mathrm{~h} ;(v i) \mathrm{NaCl}(\mathrm{aq}), 1 \mathrm{~h}$.

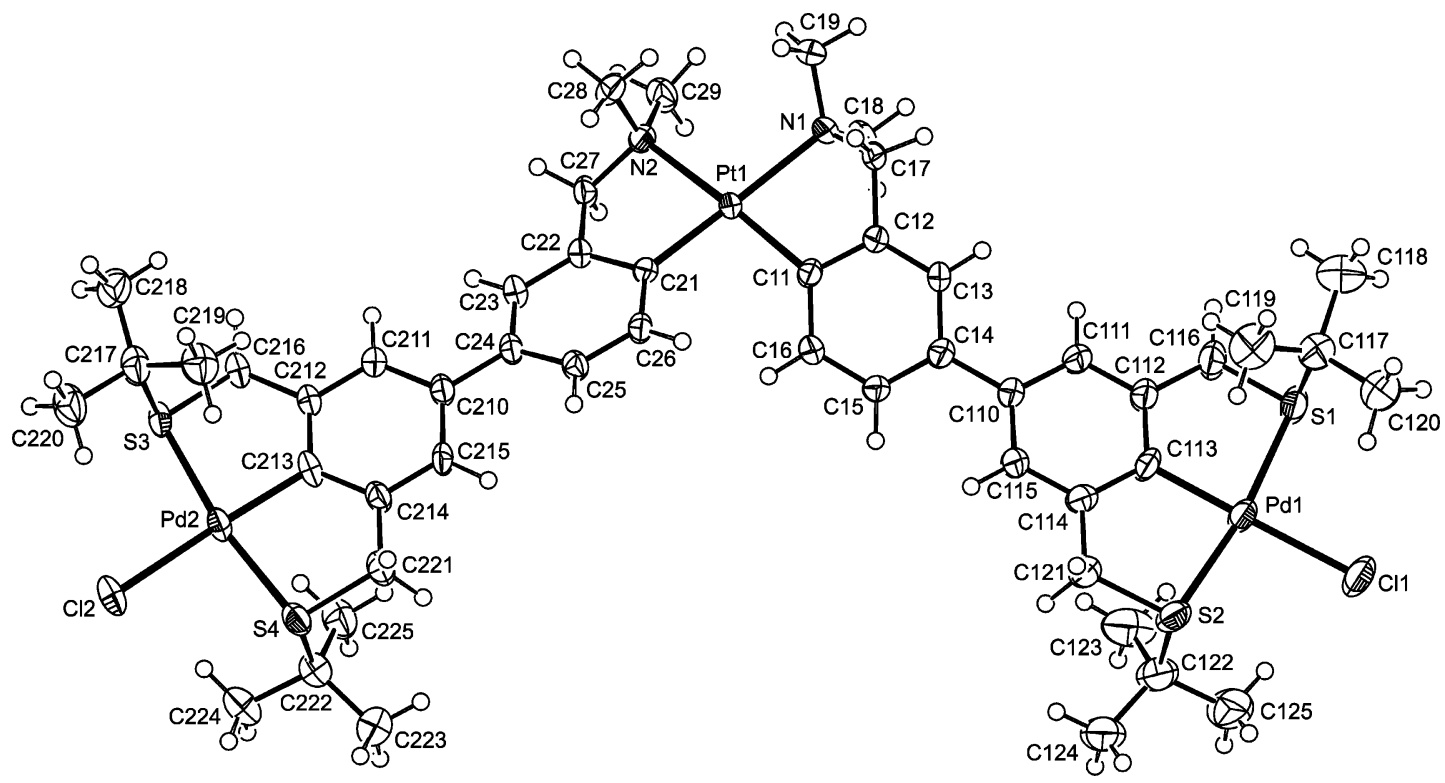

Figure 5. Displacement ellipsoid plot (50\% probability level) of the molecular structure of $\mathbf{2 5} \cdot x \mathrm{CH}_{2} \mathrm{Cl}_{2}$, with the adopted labeling scheme. Solvent molecules have been omitted for clarity.

Table 6. Selected Bond Lengths ( $\AA$ ), Bond Angles (deg), and Torsion Angles (deg) for $25 \cdot x \mathbf{C H}_{2} \mathrm{Cl}_{2}$

$\begin{array}{ll}\mathrm{Pt}(1)-\mathrm{C}(11), \mathrm{Pt}(1)-\mathrm{C}(21) & 1.999(4), 1.985(4) \\ \mathrm{Pd}(1)-\mathrm{Cl}(1), \mathrm{Pd}(2)-\mathrm{Cl}(2) & 2.4064(12), 2.4213(11) \\ \mathrm{Pd}(1)-\mathrm{S}(1), \mathrm{Pd}(1)-\mathrm{S}(2) & 2.3071(14), 2.3076(13) \\ \mathrm{N}(1)-\mathrm{Pt}(1)-\mathrm{C}(11) & 90.54(15) \\ \mathrm{C}(11)-\mathrm{Pt}(1)-\mathrm{C}(21) & 98.31(17) \\ \mathrm{Cl}(1)-\mathrm{Pd}(1)-\mathrm{C}(113), & 178.58(15), 175.83(13) \\ \mathrm{Cl}(2)-\mathrm{Pd}(2)-\mathrm{C}(213) & \\ \mathrm{S}(1)-\mathrm{Pd}(1)-\mathrm{C}(113), & 85.48(14), 85.48(14) \\ \mathrm{S}(2)-\mathrm{Pd}(1)-\mathrm{C}(113) & \\ \mathrm{Pd}(1)-\mathrm{S}(1)-\mathrm{C}(117), & 109.9(2), 109.53(19) \\ \mathrm{Pd}(1)-\mathrm{S}(2)-\mathrm{C}(122) & \\ \mathrm{C}(21)-\mathrm{Pt}(1)-\mathrm{C}(11)-\mathrm{C}(16), & 31.8(4), 25.3(4) \\ \mathrm{C}(11)-\mathrm{Pt}(1)-\mathrm{C}(21)-\mathrm{C}(26) & \\ \mathrm{S}(1)-\mathrm{Pd}(1)-\mathrm{C}(113)-\mathrm{C}(112), & 9.9(5), 6.0(4) \\ \mathrm{S}(2)-\mathrm{Pd}(1)-\mathrm{C}(113)-\mathrm{C}(114) & \\ \mathrm{C}(15)-\mathrm{C}(14)-\mathrm{C}(110)-\mathrm{C}(115) & -34.8(8)\end{array}$

Structural aspects of 24 and 25 . Solid-State Structure of 25. Single crystals of $25 \cdot x \mathrm{CH}_{2} \mathrm{Cl}_{2}$ were obtained by cooling a solution of 25 in $\mathrm{CH}_{2} \mathrm{Cl}_{2} / \mathrm{Et}_{2} \mathrm{O}$ (10: 1) at $-30{ }^{\circ} \mathrm{C}$. A plot of its molecular structure is depicted in Figure 5, while Table 6 shows a selection of bond lengths, bond angles, and torsion angles. In the crystal

$\begin{array}{ll}\mathrm{Pt}(1)-\mathrm{N}(1), \mathrm{Pt}(1)-\mathrm{N}(2) & 2.218(3), 2.208(3) \\ \mathrm{Pd}(1)-\mathrm{C}(113), \mathrm{Pd}(2)-\mathrm{C}(213) & 1.979(4), 1.976(4) \\ \mathrm{Pd}(2)-\mathrm{S}(3), \mathrm{Pd}(2)-\mathrm{S}(4) & 2.3181(12), 2.2959(13) \\ \mathrm{N}(2)-\mathrm{Pt}(1)-\mathrm{C}(21) & 80.38(15) \\ \mathrm{N}(1)-\mathrm{Pt}(1)-\mathrm{N}(2) & 101.50(13) \\ \mathrm{S}(1)-\mathrm{Pd}(1)-\mathrm{S}(2), & 170.91(5), 169.63(4) \\ \mathrm{S}(3)-\mathrm{Pd}(2)-\mathrm{S}(4) & \\ \mathrm{S}(3)-\mathrm{Pd}(2)-\mathrm{C}(213), & 85.25(14), 84.80(14) \\ \mathrm{S}(4)-\mathrm{Pd}(2)-\mathrm{C}(213) & \\ \mathrm{Pd}(2)-\mathrm{S}(3)-\mathrm{C}(217), & 107.26(18), 107.07(17) \\ \mathrm{Pd}(2)-\mathrm{S}(4)-\mathrm{C}(222) & \\ \mathrm{N}(1)-\mathrm{Pt}(1)-\mathrm{C}(11)-\mathrm{C}(12), & 14.3(3), 13.5(3) \\ \mathrm{N}(2)-\mathrm{Pt}(1)-\mathrm{C}(21)-\mathrm{C}(22) & \\ \mathrm{S}(3)-\mathrm{Pd}(2)-\mathrm{C}(213)-\mathrm{C}(212), & -8.6(4),-11.7(4) \\ \mathrm{S}(4)-\mathrm{Pd}(2)-\mathrm{C}(213)-\mathrm{C}(214) & \\ \mathrm{C}(25)-\mathrm{C}(24)-\mathrm{C}(210)-\mathrm{C}(215) & -18.9(7)\end{array}$

two diastereoisomers ( $S S, S S$ and $R R, R R$ ) are present (Figure 6). The molecular structure of $25 \cdot x \mathrm{CH}_{2} \mathrm{Cl}_{2}$ reveals a platinum(II) center that is ligated by two bidentate $C, N$-bonded amino aryl ligands in a cisfashion. Each aryl group is substituted at the paraposition with a diorganosulfide aryl moiety, which is 


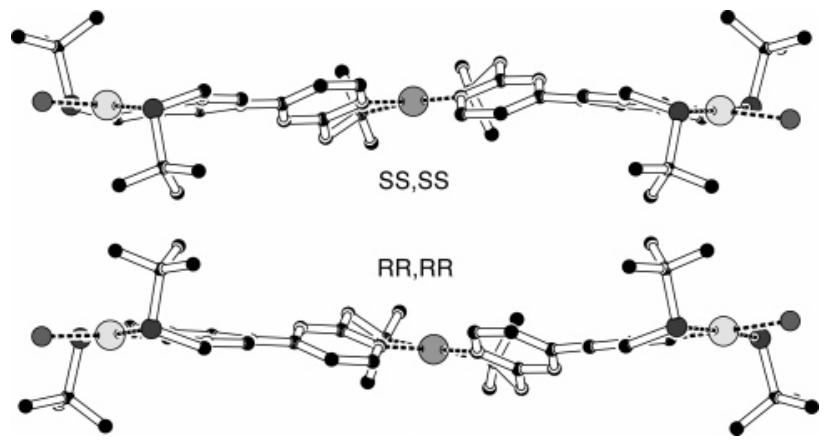

Figure 6. PLUTON plot of the two diastereoisomers of $\mathbf{2 5} \cdot x \mathrm{CH}_{2} \mathrm{Cl}_{2}$.

cyclopalladated at the position between the $\mathrm{CH}_{2} \mathrm{~S}(t-\mathrm{Bu})$ groups. This affords square-planar $\mathrm{Pd}^{\mathrm{II}}$ centers with a ligand environment that comprises a tridentate SCS coordination by the organic moiety and a chloride trans to the metal-bonded aromatic carbon atom. The $\mathrm{Pt}-\mathrm{C}$ and $\mathrm{Pt}-\mathrm{N}$ bonds fall in the range observed for cis-12 and cis-14, and the angles and torsion angles of the organoplatinum moiety fall in the range observed for cis-12. Figure 6 clearly shows that the structure is nearly flat. The palladium atoms adopt slightly distorted square-planar geometries with angles and distances that are similar to related tert-butylsulfido SCS-Pd ${ }^{\mathrm{II}}$ complexes. ${ }^{36}$ The four butyl groups are oriented anti with respect to the square planes, in axial positions, with $\mathrm{Pd}-\mathrm{S}-\mathrm{C}(t-\mathrm{Bu})$ angles of $107.07(17)-109.9(2)^{\circ}$, similar to reported $\mathrm{SCS}(t-\mathrm{Bu})-\mathrm{Pd}^{\mathrm{II}}$ complexes $(107.5(4)-$ $\left.113.5(9)^{\circ}\right) .{ }^{36}$ The torsion angles between the C,N-aryl and SCS-aryl rings of $-34.8(8)^{\circ}$ and $-18.9(7)^{\circ}(\mathrm{C}(15)-$ $\mathrm{C}(14)-\mathrm{C}(110)-\mathrm{C}(115)$ and $\mathrm{C}(25)-\mathrm{C}(24)-\mathrm{C}(210)-\mathrm{C}(215)$, respectively) fall in the range normally observed for biphenyl compounds.

Structure in Solution. The ${ }^{1} \mathrm{H}$ NMR spectra of complexes 24 and 25 in $\mathrm{CDCl}_{3}$ showed the same signals for the dimethylbenzyl amino groups as cis-10. The singlet signals of the $\mathrm{CH}_{2} \mathrm{~S}$ and $\mathrm{S}(t$-Bu) groups of $\mathbf{2 5}$ are shifted downfield with respect to the free ligand $\mathbf{2 4}, \Delta \delta$ $(\mathrm{H})=0.41$ and $0.24 \mathrm{ppm}$ for $\mathrm{CH}_{2} \mathrm{~S}$ and $\mathrm{S}(t-\mathrm{Bu})$, respectively. The resonance of the diastereotopic $\mathrm{CH}_{2} \mathrm{~S}$ protons of $\mathbf{2 5}$ is somewhat broadened due to fluxional behavior. This behavior is attributed to the pyramidal inversion of the sulfur atoms and/or to the inversion of the ring puckering, leading to a multiplicity of isomers with axial and/or equatorial positions for each $\mathrm{SBu}$ group in a single molecule. ${ }^{37}$ These two combined processes give rise to a dynamic equilibrium between two conformational isomers that make the benzylic protons nonequivalent. At lower temperatures (down to $-60{ }^{\circ} \mathrm{C}$ ) no significant changes were observed for $\mathbf{2 4}$. For complex 25, the coupling of the two diastereotopic $\mathrm{CH}_{2} \mathrm{~S}$ protons resulted in splitting of the signal into two $\mathrm{AB}$ patterns, 3.76/4.65 $\left({ }^{2} J_{\mathrm{H}-\mathrm{H}}=17 \mathrm{~Hz}\right)$ and $4.05 / 4.37\left({ }^{2} J_{\mathrm{H}-\mathrm{H}}=16 \mathrm{~Hz}\right)$ ppm at low temperatures (down to $-60{ }^{\circ} \mathrm{C}$ ). This points to the presence of two isomers; that is, the $t$-Bu groups are in axial or equatorial positions with respect to the palladium coordination plane. ${ }^{37}$ The coalescence of the

(36) (a) Errington, J.; McDonald, W. S.; Shaw, B. L. J. Chem. Soc., Dalton Trans. 1980, 2312-2314. (b) Loeb, S. J.; Shimizu, G. K. H. Wisner, J. A. Organometallics 1998, 17, 2324-2327. (c) Nakai, H.; Ogo, S.; Watanabe, Y. Organometallics 2002, 21, 1674-1678.

(37) Dupont, J.; Beydoun, N.; Pfeffer, M. J. Chem. Soc., Dalton Trans. 1989, 1715-1720.
$\mathrm{CH}_{2} \mathrm{~S}$ signals occurred at $-10{ }^{\circ} \mathrm{C}$. The singlet signal resonance of the tert-butyl groups of $\mathbf{2 5}$ splits in two singlet signals with a coalescence point of $-30{ }^{\circ} \mathrm{C}$. Although large differences for the SCS-pincer units of 25 were observed at low temperatures, no significant changes were observed for the dimethylbenzyl amino groups. Lowering the temperature to $-60{ }^{\circ} \mathrm{C}$ did not result in decoalescence of the singlet peaks of the benzylic protons of $\mathbf{2 4}$ and $\mathbf{2 5}$, as was also observed for the parent complex cis-10.

\section{Conclusions}

We have synthesized a series of new homoleptic $C, N$ ortho-chelated aminoaryl platinum(II) complexes as cisand trans-isomers in one- or two-step reactions. The cis / trans ratio is dependent on the functionalities on the aryl ring, such as halide, methyl, naphthyl, and (dimethylamino)methyl groups. Sterically demanding groups at the ortho-position favor the formation of ciscomplexes, which in that case contain a planar-chiral metal center. The trans-complexes could be irreversibly isomerized to the thermodynamically more stable cisisomers. The complexes could be further functionalized by (1) ligand displacement, (2) lithiation of the halide groups, followed by a transmetalation reaction with [SnClMe $]$, and (3) C-C Suzuki-Miyaura coupling reactions, affecting neither the conformation nor the nature of the complexes. By the latter method a bisSCS-pincer functionalized complex was prepared, which could be cyclopalladated twice in an additional reaction. This yielded an unusual neutral mixed trinuclear bispalladium/platinum corner complex, which has potential applications in the synthesis of larger (self-assembled) molecular architectures. Addition of other functionalities is of course also possible via either lithiation or $\mathrm{C}-\mathrm{C}$ coupling reactions. The halide-functionalized complexes are thus excellent precursors for the synthesis of various organometallic complexes as, for example, molecular squares. ${ }^{38}$

\section{Experimental Section}

General Comments. 4-Bromo-2-bromomethyl-1-iodobenzene (2), ${ }^{10}$ 5-bromo-1-bromomethyl-2-iodo-3-methylbenzene (3), ${ }^{10}$ 1,4-dibromo-2,5-bis(bromomethyl)benzene (4), ${ }^{10}$ 1-bromo2-dimethylaminomethylnaphthalene $(\mathbf{9}),{ }^{11}$ and 3,5-bis(bromomethyl)bromobenzene $(\mathbf{2 1})^{10}$ were synthesized according to literature procedures. All solvents and other reagents were obtained from commercial sources and were used without further purification unless stated otherwise. Reactions involving organolithium and -magnesium derivatives were carried out under an inert atmosphere of dry, oxygen-free nitrogen using standard Schlenk techniques. $\mathrm{Et}_{2} \mathrm{O}$ and THF were distilled from $\mathrm{Na} /$ /benzophenone prior to use. The ${ }^{1} \mathrm{H},{ }^{13} \mathrm{C},{ }^{31} \mathrm{P}$, and ${ }^{195} \mathrm{Pt}$ NMR spectra were recorded at 300, 75.5, 81, and $64.3 \mathrm{MHz}$, respectively, at $25^{\circ} \mathrm{C}$. Chemical shifts are reported in ppm. ${ }^{195} \mathrm{Pt}$ NMR spectra were referenced to external $\mathrm{K}_{2^{-}}$ $\mathrm{PtCl}_{4}(\delta=-1630)$. MALDI-TOF mass spectra were acquired using a Applied Biosystems Voyager System 6347, with dithranol as matrix. Elemental analyses were obtained from Kolbe, Mikroanalytisches Laboratorium (Mülheim a.d. Ruhr, Germany).

Crystal Structure Determinations. X-ray intensities were measured on a Nonius KappaCCD diffractometer with

(38) Würthner, F.; You, C.-C.; Saha-Möller, C. R. Chem. Soc. Rev. 2004, 33, 133-146, and the references therein. 
Table 7. Crystallographic Details ${ }^{a}$

\begin{tabular}{|c|c|c|c|c|}
\hline & cis-12· $\mathrm{Et}_{2} \mathrm{O}$ & cis-14 $\cdot \mathrm{xC}_{6} \mathrm{H}_{6}$ & 19 & $\mathbf{2 5} \cdot x \mathrm{CH}_{2} \mathrm{Cl}_{2}$ \\
\hline formula & $\mathrm{C}_{24} \mathrm{H}_{36} \mathrm{Br}_{2} \mathrm{~N}_{4} \mathrm{Pt} \cdot \mathrm{C}_{4} \mathrm{H}_{10} \mathrm{O}$ & $\begin{array}{l}\mathrm{C}_{26} \mathrm{H}_{28} \mathrm{~N}_{2} \mathrm{Pt}+ \\
\text { disordered solvent }\end{array}$ & $\mathrm{C}_{45} \mathrm{H}_{48} \mathrm{Br}_{2} \mathrm{~N}_{2} \mathrm{P}_{2} \mathrm{Pt}$ & $\begin{array}{l}\mathrm{C}_{50} \mathrm{H}_{70} \mathrm{Cl}_{2} \mathrm{~N}_{2} \mathrm{Pd}_{2} \mathrm{PtS}_{4} \cdot \\
2 \mathrm{CH}_{2} \mathrm{Cl}_{2}+\text { disordered solvent }\end{array}$ \\
\hline $\mathrm{fw}$ & 809.60 & $563.59[*]$ & 1033.70 & $1475.96[*]$ \\
\hline cryst size $\left[\mathrm{mm}^{3}\right]$ & $0.48 \times 0.12 \times 0.12$ & $0.21 \times 0.21 \times 0.21$ & $0.42 \times 0.18 \times 0.06$ & $0.42 \times 0.09 \times 0.06$ \\
\hline cryst color & colorless & yellow & colorless & yellow \\
\hline cryst syst & monoclinic & monoclinic & monoclinic & triclinic \\
\hline space group & $P 21 / c($ no. 14$)$ & $P 21 / c($ no. 14$)$ & $P 2 / c$ (no. 13 ) & $P \overline{1}($ no. 2$)$ \\
\hline$a[\AA]$ & $11.2540(1)$ & $9.9208(1)$ & $10.0910(10)$ & $11.0727(1)$ \\
\hline$b[\AA]$ & $13.4683(1)$ & $11.6735(1)$ & $9.3702(7)$ & $17.2827(2)$ \\
\hline$c[\AA]$ & $20.6529(2)$ & $21.8509(2)$ & $23.476(3)$ & $18.1957(2)$ \\
\hline$\alpha[\mathrm{deg}]$ & 90 & 90 & 90 & $86.1892(7)$ \\
\hline$\beta[\mathrm{deg}]$ & $100.3196(4)$ & $99.9722(5)$ & $111.232(7)$ & $79.8100(8)$ \\
\hline$\gamma$ [deg] & 90 & 90 & 90 & $82.8972(4)$ \\
\hline$V\left[\AA^{3}\right]$ & $3079.77(5)$ & $2492.33(4)$ & 2069.1(4) & $3397.27(6)$ \\
\hline$Z$ & 4 & 4 & 2 & 2 \\
\hline$D_{\text {calc }}\left[\mathrm{g} / \mathrm{cm}^{3}\right]$ & 1.746 & $1.502[*]$ & 1.659 & $1.443[*]$ \\
\hline$\mu\left[\mathrm{mm}^{-1}\right]$ & 7.177 & $5.642[*]$ & 5.433 & $2.967[*]$ \\
\hline abs corr & analytical & analytical & analytical & multiscan \\
\hline abs corr range & $0.21-0.56$ & $0.33-0.48$ & $0.32-0.70$ & $0.66-0.84$ \\
\hline measd/unique reflns & $35139 / 7012$ & $37241 / 5674$ & $30763 / 4772$ & $65488 / 15545$ \\
\hline params/restraints & $333 / 37$ & $266 / 0$ & $239 / 0$ & $620 / 0$ \\
\hline $\mathrm{R} 1 / \mathrm{wR} 2[I>2 \sigma(I)]$ & $0.0304 / 0.0684$ & $0.0208 / 0.0451$ & $0.0322 / 0.0881$ & $0.0391 / 0.1047$ \\
\hline R1/wR2 [all reflns] & $0.0364 / 0.0705$ & $0.0297 / 0.0474$ & $0.0339 / 0.0891$ & $0.0489 / 0.1104$ \\
\hline$S$ & 1.133 & 1.049 & 1.095 & 1.072 \\
\hline
\end{tabular}

${ }^{a}$ Derived parameters do not contain the contribution of the disordered solvent.

rotating anode and graphite monochromator $(\lambda=0.71073 \AA)$ at a temperature of $150(2) \mathrm{K}$. The structures were solved with automated Patterson methods ${ }^{39}\left(\right.$ cis-12 $\cdot \mathrm{Et}_{2} \mathrm{O}$, cis-14 $\cdot \mathrm{xC}_{6} \mathrm{H}_{6}$, 25. $\left.\mathrm{xCH}_{2} \mathrm{Cl}_{2}\right)$ or direct methods ${ }^{40}(\mathbf{1 9})$ and refined with SHELXL$97^{41}$ against $F^{2}$ of all reflections. Non-hydrogen atoms were refined with anisotropic displacement parameters. Hydrogen atoms were refined as rigid groups. Structure calculations and checking for higher symmetry were performed with the PLATON package. ${ }^{42}$

The crystals of cis-14 $\times \mathrm{C}_{6} \mathrm{H}_{6}$ contain large voids (374.6 $\AA^{3 /}$ unit cell) filled with severely disordered benzene solvent molecules. Their contribution to the structure factors was secured by back Fourier transformation with the SQUEEZE procedure of PLATON, ${ }^{42}$ resulting in 94 electrons/unit cell.

The crystals of $\mathbf{1 9}$ appeared to be nonmerohedrally twinned with a 2 -fold rotation about $h k l=(001)$ as twin operation. The HKLF5 twin refinement ${ }^{43}$ resulted in a twin fraction of 0.3666 (11).

The crystals of $25 \cdot x \mathrm{CH}_{2} \mathrm{Cl}_{2}$ contain ordered $\mathrm{CH}_{2} \mathrm{Cl}_{2}$ molecules and additionally large voids (678.4 $\AA^{3} /$ unit cell) filled with severely disordered $\mathrm{CH}_{2} \mathrm{Cl}_{2}$ solvent molecules. The contribution of the latter to the structure factors was secured by back Fourier transformation with the SQUEEZE procedure of PLATON, ${ }^{42}$ resulting in 178 electrons/unit cell.

Further details about the crystal structure determinations are given in Table 7.

4-Bromo-2-(dimethylamino)methyl-1-iodobenzene (5). To a solution of 2 (17.1 g, $45.5 \mathrm{mmol}$ ) was added dimethylamine ( $60 \mathrm{~mL}, 865 \mathrm{mmol}, 19$ equiv) in $\mathrm{Et}_{2} \mathrm{O}(250 \mathrm{~mL})$ at room temperature. After $2 \mathrm{~h}$ the salts were removed by filtration and the reaction mixture was concentrated in vacuo. The resulting oil was purified by flash distillation, yielding $13.4 \mathrm{~g}$ of $5(39.3 \mathrm{mmol}, 86 \%) .{ }^{1} \mathrm{H} \mathrm{NMR}\left(\mathrm{CDCl}_{3}\right): \delta 2.29\left(\mathrm{~s}, 6 \mathrm{H}, \mathrm{NCH}_{3}\right)$, $3.40\left(\mathrm{~s}, 2 \mathrm{H}, \mathrm{CH}_{2} \mathrm{~N}\right), 7.07\left(\mathrm{~d}, 1 \mathrm{H},{ }^{3} J_{\mathrm{H}-\mathrm{H}}=10 \mathrm{~Hz}, \mathrm{ArH}-5\right), 7.55$

(39) Beurskens, P. T.; Admiraal, G.; Beurskens, G.; Bosman, W. P.; Garcia-Granda, S.; Gould, R. O.; Smits, J. M. M.; Smykalla C. The DIRDIF99 program system, Technical Report of the Crystallography Laboratory; University of Nijmegen: The Netherlands, 1999.

(40) Sheldrick, G. M. SHELXS-97, Program for crystal structure solution; University of Göttingen: Germany, 1997.

(41) Sheldrick, G. M. SHELXL-97, Program for crystal structure refinement; University of Göttingen: Germany, 1997.

(42) Spek, A. L. J. Appl. Crystallogr. 2003, 36, 7-13.

(43) Herbst-Irmer, R.; Sheldrick, G. M. Acta Crystallogr. 1998, B54, $443-449$. (s, $1 \mathrm{H}, \mathrm{ArH}-3), 7.64\left(\mathrm{~d}, 1 \mathrm{H},{ }^{3} \boldsymbol{J}_{\mathrm{H}-\mathrm{H}}=10 \mathrm{~Hz}, \mathrm{ArH}-6\right),{ }^{13} \mathrm{C}\left\{{ }^{1} \mathrm{H}\right\}$ $\mathrm{NMR}\left(\mathrm{CDCl}_{3}\right): \delta 45.8\left(\mathrm{NCH}_{3}\right), 67.8\left(\mathrm{CH}_{2} \mathrm{~N}\right), 98.4(\mathrm{ArC}-1), 122.9$ (ArC-4), 131.9, 133.3, 140.8, 143.6 (ArC-2). Anal. Calcd for $\mathrm{C}_{9} \mathrm{H}_{11} \mathrm{NBrI}: \quad \mathrm{C}, 31.79 ; \mathrm{H}, 3.26 ; \mathrm{N}, 4.12$. Found: $\mathrm{C}, 31.97 ; \mathrm{H}$, $3.32 ; \mathrm{N}, 4.20$

5-Bromo-1-(dimethylamino)methyl-2-iodo-3-methylbenzene (6). Compound 3 (1.36 g, $3.49 \mathrm{mmol}$ ) was dissolved in $\mathrm{Et}_{2} \mathrm{O}(40 \mathrm{~mL})$ and treated with dimethylamine $(4 \mathrm{~mL}, 56$ mmol, 16 equiv) at room temperature. After $2 \mathrm{~h}$ the salts were removed by filtration and the reaction mixture was concentrated in vacuo. The resulting oil was purified by protonating with excess of $\mathrm{HCl}(4 \mathrm{M})$, extraction with water, addition of excess $\mathrm{NaOH}$, and extraction with $\mathrm{Et}_{2} \mathrm{O}$. Yield of 6: $0.62 \mathrm{~g}(1.75$ mmol, 50\%). ${ }^{1} \mathrm{H}$ NMR $\left(\mathrm{CDCl}_{3}\right): \delta 2.30\left(\mathrm{~s}, 6 \mathrm{H}, \mathrm{NCH}_{3}\right), 2.44(\mathrm{~s}$, $\left.3 \mathrm{H}, \mathrm{ArCH}_{3}\right), 3.44\left(\mathrm{~s}, 2 \mathrm{H}, \mathrm{CH}_{2} \mathrm{~N}\right), 7.28(\mathrm{~s}, 1 \mathrm{H}, \mathrm{ArH}-5), 7.36(\mathrm{~s}$, $1 \mathrm{H}, \mathrm{ArH}-3) .{ }^{13} \mathrm{C}\left\{{ }^{1} \mathrm{H}\right\}$ NMR $\left(\mathrm{CDCl}_{3}\right): \delta 29.4\left(\mathrm{ArCH}_{3}\right), 45.7$ $\left(\mathrm{NCH}_{3}\right), 68.7\left(\mathrm{CH}_{2} \mathrm{~N}\right), 105.7$ (ArC-4), 122.2 (ArC-1), 130.1, 131.0, 153.8, 144.1. Anal. Calcd for $\mathrm{C}_{10} \mathrm{H}_{13} \mathrm{NBrI}$ : C, 33.93; $\mathrm{H}$, 3.70; N, 3.96. Found: C, 34.02; H, 3.82; N, 3.80.

1,4-Dibromo-2,5-bis $\{$ (dimethylamino)methyl $\}$ benzene (7). To a solution of 4 (5.6 g, $13.2 \mathrm{mmol})$ in $\mathrm{Et}_{2} \mathrm{O}(130$ $\mathrm{mL}$ ) was added dimethylamine (15 mL, $216 \mathrm{mmol}, 16$ equiv) at room temperature. The suspension was stirred for $2 \mathrm{~h}$, after which the salts were removed by filtration. The reaction mixture was washed with brine $(40 \mathrm{~mL}, 2 \times)$. Evaporating the solvent in vacuo yielded $4.0 \mathrm{~g}$ of $\mathbf{7}$ as a white solid (11.4 mmol, $87 \%) .{ }^{1} \mathrm{H}$ NMR $\left(\mathrm{CDCl}_{3}\right): \delta 2.31\left(\mathrm{~s}, 12 \mathrm{H}, \mathrm{NCH}_{3}\right), 3.49(\mathrm{~s}, 4 \mathrm{H}$, $\left.\mathrm{CH}_{2} \mathrm{~N}\right), 7.64(\mathrm{~s}, 2 \mathrm{H}, \mathrm{ArH}-3,6) .{ }^{13} \mathrm{C}\left\{{ }^{1} \mathrm{H}\right\} \mathrm{NMR}\left(\mathrm{CDCl}_{3}\right): \delta 45.7$ $\left(\mathrm{NCH}_{3}\right), 62.7\left(\mathrm{CH}_{2} \mathrm{~N}\right), 123.5(\mathrm{ArC}-1,4), 134.6$ (ArC-3,6), 138.7 (ArC-2,5). Anal. Calcd for $\mathrm{C}_{12} \mathrm{H}_{18} \mathrm{~N}_{2} \mathrm{Br}_{2}$ : C, 41.17; H, 5.18; N, 8.00. Found: C, 41.08; H, 5.03; N, 7.88.

1,4-Diiodo-2,5-bis $\{$ (dimethylamino)methyl $\}$ benzene (8). Compound 7 ( $1.9 \mathrm{~g}, 5.5 \mathrm{mmol})$ was dissolved in $\mathrm{Et}_{2} \mathrm{O}(40 \mathrm{~mL})$, and to this solution was added $n$-BuLi $(7.8 \mathrm{~mL}, 1.6 \mathrm{M}$ in hexane, $12.5 \mathrm{mmol}, 2.3$ equiv) at $-78^{\circ} \mathrm{C}$. The reaction mixture was stirred for $15 \mathrm{~min}$ at this temperature, after which the suspension was allowed to reach room temperature and stirred for $45 \mathrm{~min}$. The reaction mixture was quenched with a solution of 1,2-diiodoethane ( $3.2 \mathrm{~g}, 11.5 \mathrm{mmol}, 2.1$ equiv) in $\mathrm{Et}_{2} \mathrm{O}$ (30 $\mathrm{mL}$ ) and stirred for $15 \mathrm{~min}$. The mixture was acidified with a $2 \mathrm{M}$ solution of $\mathrm{HCl}(20 \mathrm{~mL})$, and the aqueous layer was separated from the organic layer and washed with $\mathrm{Et}_{2} \mathrm{O}(40$ $\mathrm{mL}$ ). The aqueous layer was made basic with $\mathrm{KOH}$ pellets until the amino compound precipitated from solution. Extracting 
with $\mathrm{Et}_{2} \mathrm{O}$ and removal of the solvent yielded $2.14 \mathrm{~g}$ of $\mathbf{8}$ as an off-white powder $(4.8 \mathrm{mmol}, 88 \%) .{ }^{1} \mathrm{H} \mathrm{NMR}\left(\mathrm{CDCl}_{3}\right): \delta 2.32$ $\left(\mathrm{s}, 12 \mathrm{H}, \mathrm{NCH}_{3}\right), 3.42\left(\mathrm{~s}, 4 \mathrm{H}, \mathrm{CH}_{2} \mathrm{~N}\right), 7.86(\mathrm{~s}, 2 \mathrm{H}, \mathrm{ArH}-3,6) .{ }^{13} \mathrm{C}-$ $\left\{{ }^{1} \mathrm{H}\right\}$ NMR $\left(\mathrm{CDCl}_{3}\right): \delta 45.6\left(\mathrm{NCH}_{3}\right), 67.1\left(\mathrm{CH}_{2} \mathrm{~N}\right), 100.3(\mathrm{ArC}-$ 1,4), 140.5 (ArC-3,6), 141.9 (ArC-2,5). Anal. Calcd for $\mathrm{C}_{12} \mathrm{H}_{18} \mathrm{~N}_{2} \mathrm{I}_{2}$ : C, 32.46; H, 4.09; N, 6.31. Found: C, 32.58; H, 4.15; N, 6.39.

cis-[Pt $\left.\left(\mathrm{C}_{6} \mathrm{H}_{3} \mathrm{Br}-4\left\{\mathrm{CH}_{2} \mathrm{NMe}_{2}\right\}-2\right)_{2}\right]($ cis-10) and trans-[Pt$\left.\left(\mathrm{C}_{6} \mathrm{H}_{3} \mathrm{Br}-4\left\{\mathrm{CH}_{2} \mathrm{NMe}_{2}\right\}-2\right)_{2}\right]$ (trans-10). To a solution of 5 (1.4 g, $4.12 \mathrm{mmol})$ in $\mathrm{Et}_{2} \mathrm{O}(30 \mathrm{~mL})$ was added $n$-BuLi $(4.16 \mathrm{mmol}$, $1.6 \mathrm{M}$ in hexane, $2.6 \mathrm{~mL}, 1$ equiv) at $-78{ }^{\circ} \mathrm{C}$. The reaction mixture was stirred for $5 \mathrm{~min}$, after which a suspension of trans- $\left[\mathrm{PtCl}_{2}\left(\mathrm{SMe}_{2}\right)_{2}\right]\left(0.80 \mathrm{~g}, 2.06 \mathrm{mmol}, 0.5\right.$ equiv) in $\mathrm{Et}_{2} \mathrm{O}$ (10 $\mathrm{mL}$ ) was added. The off-white suspension was allowed to warm to room temperature and stirred for $2 \mathrm{~h}$. The precipitate was isolated by centrifugation, dissolved in $\mathrm{CH}_{2} \mathrm{Cl}_{2}$, and filtered over Celite. The solvent was removed in vacuo. The remaining white solid (ratio cis/trans $=85: 15$ ) was washed with $\mathrm{THF}$ $(10 \mathrm{~mL})$ and precipitated from refluxing THF to give $0.56 \mathrm{~g}$ $(0.90 \mathrm{mmol}, 44 \%)$ of the cis-complex cis-10 as a white solid. The THF mother liquor was evaporated in vacuo to yield a mixture of trans $\mathbf{- 1 0}$ and cis-10 as a white solid (cis/trans $=$ 25:75). cis-10: ${ }^{1} \mathrm{H}$ NMR $\left(\mathrm{CDCl}_{3}\right): \delta 2.80\left(\mathrm{~s},{ }^{3} \boldsymbol{J}_{\mathrm{Pt}-\mathrm{H}}=11 \mathrm{~Hz}\right.$, $\left.12 \mathrm{H}, \mathrm{NCH}_{3}\right), 3.85\left(\mathrm{~s},{ }^{3} J_{\mathrm{Pt}-\mathrm{H}}=18 \mathrm{~Hz}, 4 \mathrm{H}, \mathrm{CH}_{2} \mathrm{~N}\right), 7.11\left(\mathrm{~d},{ }^{3} J_{\mathrm{H}-\mathrm{H}}\right.$ unresolved, $2 \mathrm{H}, \mathrm{ArH}-5), 7.12(\mathrm{~s}, 2 \mathrm{H}, \mathrm{ArH}-3), 7.25\left(\mathrm{~d},{ }^{3} J_{\mathrm{H}-\mathrm{H}}=\right.$ $\left.12 \mathrm{~Hz}^{3} \boldsymbol{J}_{\mathrm{Pt}-\mathrm{H}}=18 \mathrm{~Hz}, 2 \mathrm{H}, \mathrm{ArH}-6\right) .{ }^{13} \mathrm{C}\left\{{ }^{1} \mathrm{H}\right\} \mathrm{NMR}\left(\mathrm{CDCl}_{3}\right): \delta$ $50.3\left(\mathrm{NCH}_{3}\right), 73.1\left({ }^{2} J_{\mathrm{Pt}-\mathrm{C}}=55 \mathrm{~Hz}, \mathrm{CH}_{2} \mathrm{~N}\right), 116.5(\mathrm{ArC}-4), 124.3$ $\left({ }^{3} J_{\mathrm{Pt}-\mathrm{C}}=45 \mathrm{~Hz}, \mathrm{ArC}-3\right), 128.9\left({ }^{3} \mathrm{~J}_{\mathrm{Pt}-\mathrm{C}}=91 \mathrm{~Hz}, \mathrm{ArC}-5\right), 137.4$ $\left({ }^{1} J_{\mathrm{Pt}-\mathrm{C}}=1182 \mathrm{~Hz}, \mathrm{C}_{\mathrm{ipso}}\right), 140.2\left({ }^{2} J_{\mathrm{Pt}-\mathrm{C}}=116 \mathrm{~Hz}, \mathrm{ArC}-6\right), 149.6$ (ArC-2). ${ }^{195} \mathrm{Pt}\left\{{ }^{1} \mathrm{H}\right\} \mathrm{NMR}\left(\mathrm{CDCl}_{3}\right): \delta-3387.9$. Anal. Calcd for $\mathrm{C}_{18} \mathrm{H}_{22} \mathrm{~N}_{2} \mathrm{PtBr}_{2}$ : C, 34.80; H, 3.57; N, 4.51. Found: C, 34.71; $\mathrm{H}, 3.61 ; \mathrm{N}, 4.50$. trans-10: ${ }^{1} \mathrm{H}$ NMR $\left(\mathrm{CDCl}_{3}\right): \delta 3.02\left(\mathrm{~s},{ }^{3} \boldsymbol{J}_{\mathrm{Pt}-\mathrm{H}}\right.$ $\left.=43 \mathrm{~Hz}, 12 \mathrm{H}, \mathrm{NCH}_{3}\right), 3.96\left(\mathrm{~s},{ }^{3} J_{\mathrm{Pt}-\mathrm{H}}=40 \mathrm{~Hz}, 4 \mathrm{H}, \mathrm{CH}_{2} \mathrm{~N}\right)$, $7.22\left(\mathrm{~d},{ }^{3} J_{\mathrm{H}-\mathrm{H}}=8 \mathrm{~Hz}, 2 \mathrm{H}, \mathrm{ArH}-5\right), 7.28(\mathrm{~s}, 2 \mathrm{H}, \mathrm{ArH}-3), 7.37$ $\left(\mathrm{d},{ }^{3} \boldsymbol{J}_{\mathrm{H}-\mathrm{H}}=8 \mathrm{~Hz},{ }^{3} \boldsymbol{J}_{\mathrm{Pt}-\mathrm{H}}\right.$ unresolved, $\left.2 \mathrm{H}, \mathrm{ArH}-6\right) .{ }^{13} \mathrm{C}\left\{{ }^{1} \mathrm{H}\right\} \mathrm{NMR}$ $\left(\mathrm{CDCl}_{3}\right): \delta 53.8\left(\mathrm{NCH}_{3}\right), 79.5\left(\mathrm{CH}_{2} \mathrm{~N}\right), 116.4(\mathrm{ArC}-4), 124.0$ $\left({ }^{3} J_{\mathrm{Pt}-\mathrm{C}}=45 \mathrm{~Hz}, \mathrm{ArC}-6\right), 128.0\left({ }^{3} J_{\mathrm{Pt}-\mathrm{C}}=37 \mathrm{~Hz}, \mathrm{ArC}-3,5\right), 136.5$ $\left({ }^{3} J_{\mathrm{Pt}-\mathrm{C}}=43 \mathrm{~Hz}, \mathrm{ArC}-3,5\right), 151.5(\mathrm{ArC}-2), 167.6\left(\mathrm{ArC}_{\mathrm{ipso}}\right) .{ }^{195} \mathrm{Pt}-$ $\left\{{ }^{1} \mathrm{H}\right\} \mathrm{NMR}\left(\mathrm{CDCl}_{3}\right): \delta-2871.5$.

cis $-\left[\mathbf{P t}\left(\mathrm{C}_{6} \mathrm{H}_{3}\left\{\mathrm{CH}_{2} \mathrm{NMe}_{2}\right\}-2-\mathrm{Br}-4-\mathrm{Me}-6\right)_{2}\right]$ (11). To a solution of $6(0.62 \mathrm{~g}, 1.75 \mathrm{mmol})$ in $\mathrm{Et}_{2} \mathrm{O}(15 \mathrm{~mL})$ at $-78^{\circ} \mathrm{C}$ was added $n$-BuLi (1.6 $\mathrm{M}$ in hexane, $1.1 \mathrm{~mL}, 1.76 \mathrm{mmol}, 1$ equiv). The resulting yellow suspension was stirred for $10 \mathrm{~min}$ at this temperature, after which neat trans- $\left[\mathrm{PtCl}_{2}\left(\mathrm{SMe}_{2}\right)_{2}\right](0.32 \mathrm{~g}$, $0.81 \mathrm{mmol}, 0.46$ equiv) was added. The reaction mixture was warmed to room temperature and stirred for $3 \mathrm{~h}$. The solvent was removed in vacuo. The mixture was dissolved in $\mathrm{CH}_{2} \mathrm{Cl}_{2}$ and filtered over Celite. After removal of the solvent by evaporation, the solid was washed with $\mathrm{Et}_{2} \mathrm{O}(5 \mathrm{~mL})$ and pentane $(5 \mathrm{~mL}, 2 \times)$, yielding $0.4 \mathrm{~g}$ of the cis-isomer of $\mathbf{1 1}$ as an off-white solid (0.62 mmol, 77\%). ${ }^{1} \mathrm{H} \mathrm{NMR}\left(\mathrm{CDCl}_{3}\right): \delta 1.99$ $\left(\mathrm{s}, 6 \mathrm{H}, \mathrm{ArCH}_{3}\right), 2.37\left(\mathrm{~s},{ }^{3} J_{\mathrm{Pt}-\mathrm{H}}=18 \mathrm{~Hz}, 6 \mathrm{H}, \mathrm{NCH}_{3}\right), 2.94(\mathrm{~s}$, $\left.{ }^{3} \boldsymbol{J}_{\mathrm{Pt}-\mathrm{H}}=12 \mathrm{~Hz}, 6 \mathrm{H}, \mathrm{NCH}_{3}\right), 3.28 / 4.48\left(\mathrm{AX},{ }^{2} \boldsymbol{J}_{\mathrm{H}-\mathrm{H}}=12 \mathrm{~Hz}\right.$, ${ }^{3} J_{\mathrm{Pt}-\mathrm{H}}$ unresolved, $\left.4 \mathrm{H}, \mathrm{CH}_{2} \mathrm{~N}\right), 6.87\left(\mathrm{~s},{ }^{4} \boldsymbol{J}_{\mathrm{Pt}-\mathrm{H}}=24 \mathrm{~Hz}, 2 \mathrm{H}, \mathrm{ArH}-\right.$ 3), $6.92(\mathrm{~s}, 2 \mathrm{H}, \mathrm{ArH}-5) .{ }^{13} \mathrm{C}\left\{{ }^{1} \mathrm{H}\right\} \mathrm{NMR}\left(\mathrm{C}_{6} \mathrm{D}_{6}\right): \delta 26.5\left({ }^{3} \mathrm{~J}_{\mathrm{Pt}-\mathrm{C}}=\right.$ $\left.81 \mathrm{~Hz}, \mathrm{ArCH}_{3}\right), 47.8\left(\mathrm{NCH}_{3}\right), 50.8\left(\mathrm{NCH}_{3}\right), 73.9\left({ }^{2} J_{\mathrm{Pt}-\mathrm{C}}=57\right.$ $\left.\mathrm{Hz}, \mathrm{CH}_{2} \mathrm{~N}\right), 115.7\left(\right.$ ArC-4) $122.0\left({ }^{3} \mathrm{~J}_{\mathrm{Pt}-\mathrm{C}}=42 \mathrm{~Hz}, \mathrm{ArC}-3\right), 128.8$ $\left({ }^{3} J_{\mathrm{Pt}-\mathrm{C}}=65 \mathrm{~Hz}, \mathrm{ArC}-5\right), 138.9\left({ }^{1} J_{\mathrm{Pt}-\mathrm{C}}=1215 \mathrm{~Hz}, \mathrm{ArC}_{\mathrm{ipso}}\right), 148.0$ (ArC-6), 148.7 (ArC-2). ${ }^{195} \mathrm{Pt}\left\{{ }^{1} \mathrm{H}\right\} \mathrm{NMR}\left(\mathrm{CDCl}_{3}\right): \delta-3470.3$. Anal. Calcd for $\mathrm{C}_{20} \mathrm{H}_{26} \mathrm{~N}_{2} \mathrm{PtBr}_{2}$ : C, 36.99; H, 4.04; N, 4.31. Found: C, 36.91; H, 3.94; N, 4.25.

cis- $\left[\mathrm{Pt}\left(\mathrm{C}_{6} \mathrm{H}_{2} \mathrm{Br}-4-\left\{\mathrm{CH}_{2} \mathrm{NMe}_{2}\right\}_{2}-2,5\right)_{2}\right]($ cis-12) and trans$\left[\mathrm{Pt}\left(\mathrm{C}_{6} \mathrm{H}_{2} \mathrm{Br}-4\left\{\mathrm{CH}_{2} \mathrm{NMe}_{2}\right\}_{2}-2,5\right)_{2}\right]$ (trans-12). To a suspension of $7(0.39 \mathrm{~g}, 1.12 \mathrm{mmol})$ in $\mathrm{Et}_{2} \mathrm{O}(20 \mathrm{~mL})$ was added $n$-BuLi (1.12 mmol, $1.6 \mathrm{M}$ in hexane, $0.7 \mathrm{~mL}, 1$ equiv) at $-78^{\circ} \mathrm{C}$. The green suspension was stirred for $15 \mathrm{~min}$ at this temperature, after which trans- $\left[\mathrm{PtCl}_{2}\left(\mathrm{SMe}_{2}\right)_{2}\right](0.22 \mathrm{~g}, 0.56 \mathrm{mmol}, 0.5$ equiv $)$ in $\mathrm{Et}_{2} \mathrm{O}(10 \mathrm{~mL})$ was added. The reaction mixture was stirred for $15 \mathrm{~min}$ at $-78{ }^{\circ} \mathrm{C}$, warmed to room temperature (30 min), and stirred for an additional $3 \mathrm{~h}$. All solvents were then evaporated, and the yellow solid was dissolved in $\mathrm{CH}_{2} \mathrm{Cl}_{2}$ and filtered over Celite. Evaporation of the solvent in vacuo and washing the solid with $\mathrm{Et}_{2} \mathrm{O}(5 \mathrm{~mL})$ and pentane $(5 \mathrm{~mL}, 2 \times)$ yielded $0.20 \mathrm{~g}(0.27 \mathrm{mmol}, 48 \%)$ of $\mathbf{1 2}$ as a mixture of the cis(cis-12) and trans-isomers (trans-12). Ratio cis/trans $=60: 40$. The cis-complex was isolated by precipitation from a $\mathrm{CH}_{2} \mathrm{Cl}_{2} /$ $\mathrm{Et}_{2} \mathrm{O}$ mixture. Crystals of the cis-complex (colorless needles) were obtained by slow distillation of $\mathrm{Et}_{2} \mathrm{O}$ in a saturated solution of cis-12 in $\mathrm{CH}_{2} \mathrm{Cl}_{2} / \mathrm{EtOH}$ (90:10) for 2 days at room temperature. cis-12: ${ }^{1} \mathrm{H}$ NMR $\left(\mathrm{C}_{6} \mathrm{D}_{6}\right): \delta 1.98\left(\mathrm{~s},{ }^{3} J_{\mathrm{Pt}-\mathrm{H}}=19\right.$ $\left.\mathrm{Hz}, 12 \mathrm{H}, \mathrm{CH}_{2} \mathrm{NCH}_{3}-2\right), 2.23\left(\mathrm{~s}, 12 \mathrm{H}, \mathrm{CH}_{2} \mathrm{NCH}_{3}-5\right), 3.20(\mathrm{~s}$, $\left.{ }^{3} J_{\mathrm{Pt}-\mathrm{H}}=13 \mathrm{~Hz}, 4 \mathrm{H}, \mathrm{CH}_{2} \mathrm{NCH}_{3}-2\right), 3.64\left(\mathrm{~s}, 4 \mathrm{H}, \mathrm{CH}_{2} \mathrm{NCH}_{3}-5\right)$, $7.28\left(\mathrm{~s},{ }^{4} J_{\mathrm{Pt}-\mathrm{H}}=16 \mathrm{~Hz}, 2 \mathrm{H}, \mathrm{ArH}-3\right), 7.90\left(\mathrm{~s},{ }^{3} \mathrm{~J}_{\mathrm{Pt}-\mathrm{H}}=64 \mathrm{~Hz}\right.$, $2 \mathrm{H}, \mathrm{ArH}-6) .{ }^{13} \mathrm{C}\left\{{ }^{1} \mathrm{H}\right\} \mathrm{NMR}\left(\mathrm{C}_{6} \mathrm{D}_{6}\right): \delta 45.5\left(\mathrm{CH}_{2} \mathrm{NCH}_{3}-2\right), 49.2$ $\left(\mathrm{CH}_{2} \mathrm{NCH}_{3}-5\right) 64.0\left(\mathrm{CH}_{2} \mathrm{NCH}_{3}-2\right), 72.4\left(\mathrm{CH}_{2} \mathrm{NCH}_{3}-5\right), 119.5$ (ArC-4), 125.4 (ArC-3), 135.5 (ArC-5), $139.5\left(\mathrm{ArC}_{\mathrm{ipso}}\right), 142.2$ (ArC-6), 148.5 (ArC-2). ${ }^{195} \mathrm{Pt}\left\{{ }^{1} \mathrm{H}\right\} \mathrm{NMR}\left(\mathrm{CDCl}_{3}\right): \delta-3384.6$. Anal. Calcd for $\mathrm{C}_{24} \mathrm{H}_{36} \mathrm{~N}_{4} \mathrm{Br}_{2} \mathrm{Pt}$ : C, 39.19; H, 4.93; N, 7.62. Found: $\mathrm{C}, 39.25 ; \mathrm{H}, 4.93 ; \mathrm{N}, 7.51$. trans-12: ${ }^{1} \mathrm{H}$ NMR $\left(\mathrm{C}_{6} \mathrm{D}_{6}\right)$ : $\delta 2.29\left(\mathrm{~s}, 12 \mathrm{H}, \mathrm{CH}_{2} \mathrm{NCH}_{3}-5\right), 2.59\left(\mathrm{~s},{ }^{3} J_{\mathrm{Pt}-\mathrm{H}}=44 \mathrm{~Hz}, 12 \mathrm{H}, \mathrm{CH}_{2-}\right.$ $\left.\mathrm{NCH}_{3}-2\right), 3.33\left(\mathrm{~s},{ }^{3} \mathrm{~J}_{\mathrm{Pt}-\mathrm{H}}=40 \mathrm{~Hz}, 4 \mathrm{H}, \mathrm{CH}_{2} \mathrm{NCH}_{3}-2\right), 3.76(\mathrm{~s}$, $\left.4 \mathrm{H}, \mathrm{CH}_{2} \mathrm{NCH}_{3}-5\right), 7.37\left(\mathrm{~s},{ }^{4} J_{\mathrm{Pt}-\mathrm{H}}=28 \mathrm{~Hz}, 2 \mathrm{H}, \mathrm{ArH}-3\right), 7.85(\mathrm{~s}$, $\left.{ }^{3} J_{\mathrm{Pt}-\mathrm{H}}=25 \mathrm{~Hz}, 2 \mathrm{H}, \mathrm{ArH}-6\right) .{ }^{13} \mathrm{C}\left\{{ }^{1} \mathrm{H}\right\} \mathrm{NMR}\left(\mathrm{C}_{6} \mathrm{D}_{6}\right): \delta 45.7$ $\left(\mathrm{CH}_{2} \mathrm{NCH}_{3}-2\right), 53.2\left(\mathrm{CH}_{2} \mathrm{NCH}_{3}-5\right) 64.2\left(\mathrm{CH}_{2} \mathrm{NCH}_{3}-2\right), 78.9\left(\mathrm{CH}_{2}-\right.$ $\mathrm{NCH}_{3}-5$ ), 119.2 (ArC-4), 125.2 (ArC-3), 134.3 (ArC-5), 137.9 (ArC-6), 150.5 (ArC-2), $168.8\left(\mathrm{ArC}_{\mathrm{ipso}}\right) .{ }^{195} \mathrm{Pt}\left\{{ }^{1} \mathrm{H}\right\} \mathrm{NMR}\left(\mathrm{CDCl}_{3}\right)$ : $\delta-2865.4$.

cis- $\left[\mathrm{Pt}\left(\mathrm{C}_{6} \mathrm{H}_{2} \mathrm{I}-4\left\{\mathrm{CH}_{2} \mathrm{NMe}_{2}\right\}_{2}-2,5\right)_{2}\right]$ (cis-13) and trans $-[\mathrm{Pt}-$ $\left.\left(\mathrm{C}_{6} \mathrm{H}_{2} \mathrm{I}-4\left\{\mathrm{CH}_{2} \mathrm{NMe}_{2}\right\}_{2}-\mathbf{2 , 5}\right)_{2}\right]$ (trans-13). The synthesis of cis13 and trans-13 is similar to the synthesis of cis-12 and trans12, but starts from $8(0.5 \mathrm{~g}, 1.1 \mathrm{mmol})$ in $\mathrm{Et}_{2} \mathrm{O}(30 \mathrm{~mL})$ with $n$-BuLi $(0.7 \mathrm{~mL}, 1.6 \mathrm{M}$ in hexane, $1.1 \mathrm{mmol}, 1$ equiv) and trans$\left[\mathrm{PtCl}_{2}\left(\mathrm{SMe}_{2}\right)_{2}\right](0.22 \mathrm{~g}, 0.6 \mathrm{mmol}, 0.5$ equiv). The reaction mixture was concentrated in vacuo, dissolved in $\mathrm{CH}_{2} \mathrm{Cl}_{2}$, and filtered over Celite. After removal of the solvent in vacuo and washing with hexane $(5 \mathrm{~mL})$, an off-white powder was obtained. The cis/trans ratio was 47:53. Yield of 13: $0.43 \mathrm{~g}(0.5$ mmol, 46\%). cis-13: ${ }^{1} \mathrm{H}$ NMR $\left(\mathrm{C}_{6} \mathrm{D}_{6}\right): \delta 1.96\left(\mathrm{~s},{ }^{3} \boldsymbol{J}_{\mathrm{Pt}-\mathrm{H}}=10\right.$ $\left.\mathrm{Hz}, 12 \mathrm{H}, \mathrm{CH}_{2} \mathrm{NCH}_{3}-2\right), 2.22\left(\mathrm{~s}, 12 \mathrm{H}, \mathrm{CH}_{2} \mathrm{NCH}_{3}-5\right), 3.18$ (s, $\left.{ }^{3} \boldsymbol{J}_{\mathrm{Pt}-\mathrm{H}}=17 \mathrm{~Hz}, 4 \mathrm{H}, \mathrm{CH}_{2} \mathrm{NCH}_{3}-2\right), 3.55\left(\mathrm{~s}, 4 \mathrm{H}, \mathrm{CH}_{2} \mathrm{NCH}_{3}-5\right)$, 7.57 (s, 2H, ArH-3), $7.84\left(\mathrm{~s},{ }^{3} J_{\mathrm{Pt}-\mathrm{H}}=63 \mathrm{~Hz}, 2 \mathrm{H}, \mathrm{ArH}-6\right) .{ }^{13} \mathrm{C}-$ $\left\{{ }^{1} \mathrm{H}\right\} \mathrm{NMR}\left(\mathrm{C}_{6} \mathrm{D}_{6}\right): \delta 45.6\left(\mathrm{CH}_{2} \mathrm{NCH}_{3}-2\right), 49.4\left(\mathrm{CH}_{2} \mathrm{NCH}_{3}-5\right)$ $68.4\left(\mathrm{CH}_{2} \mathrm{NCH}_{3}-2\right), 72.3\left(\mathrm{CH}_{2} \mathrm{NCH}_{3}-5\right), 94.6$ (ArC-4), 132.1 (ArC-3), 138.6 (ArC-5), 140.9 ( ArC $_{\text {ipso }}$ ), 142.2 (ArC-6), 149.3 (ArC-2). ${ }^{195} \mathrm{Pt}\left\{{ }^{1} \mathrm{H}\right\}$ NMR $\left(\mathrm{C}_{6} \mathrm{D}_{6}\right): \delta-3390.7$. Anal. Calcd for $\mathrm{C}_{24} \mathrm{H}_{36} \mathrm{~N}_{4} \mathrm{I}_{2} \mathrm{Pt}$ : C, 34.75; H, 4.37; N, 6.75. Found: C, 34.63; H, 4.31; $\mathrm{N}, 6.79$. trans-13: ${ }^{1} \mathrm{H} \mathrm{NMR}\left(\mathrm{C}_{6} \mathrm{D}_{6}\right): \delta 2.28\left(\mathrm{~s}, 12 \mathrm{H}, \mathrm{CH}_{2^{-}}\right.$ $\left.\mathrm{NCH}_{3}-5\right), 2.58\left(\mathrm{~s},{ }^{3} J_{\mathrm{Pt}-\mathrm{H}}=45 \mathrm{~Hz}, 12 \mathrm{H}, \mathrm{CH}_{2} \mathrm{NCH}_{3}-2\right), 3.31(\mathrm{~s}$, $\left.{ }^{3} \boldsymbol{J}_{\mathrm{Pt}-\mathrm{H}}=40 \mathrm{~Hz}, 4 \mathrm{H}, \mathrm{CH}_{2} \mathrm{NCH}_{3}-2\right), 3.67\left(\mathrm{~s}, 4 \mathrm{H}, \mathrm{CH}_{2} \mathrm{NCH}_{3}-5\right)$, $7.64(\mathrm{~s}, 2 \mathrm{H}, \mathrm{ArH}-3), 7.79\left(\mathrm{~s},{ }^{3} J_{\mathrm{Pt}-\mathrm{H}}=25 \mathrm{~Hz}, 2 \mathrm{H}, \mathrm{ArH}-6\right) .{ }^{13} \mathrm{C}-$ $\left\{{ }^{1} \mathrm{H}\right\} \operatorname{NMR}\left(\mathrm{C}_{6} \mathrm{D}_{6}\right): \delta 45.7\left(\mathrm{CH}_{2} \mathrm{NCH}_{3}-2\right), 53.2\left(\mathrm{CH}_{2} \mathrm{NCH}_{3}-5\right)$ $68.9\left(\mathrm{CH}_{2} \mathrm{NCH}_{3}-2\right), 78.5\left(\mathrm{CH}_{2} \mathrm{NCH}_{3}-5\right), 94.3$ (ArC-4), 131.8 (ArC-3), 137.1 (ArC-5), 137.7 (ArC-6), 151.1 (ArC-2), 169.9 $\left(\mathrm{ArC}_{\mathrm{ipso}}\right) .{ }^{195} \mathrm{Pt}\left\{{ }^{1} \mathrm{H}\right\} \mathrm{NMR}\left(\mathrm{C}_{6} \mathrm{D}_{6}\right): \delta-2880.1$.

cis-[Pt $\left.\left(\mathrm{C}_{10} \mathrm{H}_{6}\left\{\mathrm{CH}_{2} \mathrm{NMe}_{2}\right\}-2\right)_{2}\right]$ (cis-14) and trans-[Pt$\left.\left(\mathrm{C}_{10} \mathrm{H}_{6}\left\{\mathrm{CH}_{2} \mathrm{NMe}_{2}\right\}-2\right)_{2}\right]$ (trans-14). To a solution of $\mathbf{9}(0.27 \mathrm{~g}$, $1.02 \mathrm{mmol})$ in $\mathrm{Et}_{2} \mathrm{O}(40 \mathrm{~mL})$ was added $n-\mathrm{BuLi}(1.6 \mathrm{M}$ in hexane, $0.64 \mathrm{~mL}, 1.02 \mathrm{mmol}, 1.0$ equiv) at $-78{ }^{\circ} \mathrm{C}$. After 30 $\mathrm{min}$ at this temperature, trans-[ $\left[\mathrm{PtCl}_{2}\left(\mathrm{SMe}_{2}\right)_{2}\right](180 \mathrm{mg}, 0.46$ mmol, 0.45 equiv) was added. The mixture was stirred for 15 min at $-78^{\circ} \mathrm{C}$ and slowly warmed to room temperature. The reaction was complete after $2 \mathrm{~h}$. The solvents were evaporated in vacuo. The remaining solid was dissolved in $\mathrm{CH}_{2} \mathrm{Cl}_{2}$ and filtered over Celite. Subsequent evaporation of the solvent and washing the remaining yellow solid with pentane $(5 \mathrm{~mL}, 3 \times)$ yielded 14 as a mixture of cis- and trans-isomers. Ratio cis / trans $=85: 15$. Yield of 14: $0.21 \mathrm{~g}(0.38 \mathrm{mmol}, 82 \%)$. The cisisomer was obtained pure by crystallization from a saturated solution of 14 in benzene/pentane $(9: 1)$. cis-14: ${ }^{1} \mathrm{H}$ NMR $\left(\mathrm{C}_{6} \mathrm{D}_{6}\right): \delta 1.93\left(\mathrm{~s},{ }^{3} \boldsymbol{J}_{\mathrm{Pt}-\mathrm{H}}\right.$ unresolved, $\left.6 \mathrm{H}, \mathrm{NCH}_{3}\right), 2.20\left(\mathrm{~s},{ }^{3} \boldsymbol{J}_{\mathrm{Pt}-\mathrm{H}}\right.$ unresolved, $\left.6 \mathrm{H}, \mathrm{NCH}_{3}\right), 3.08 / 4.46\left(\mathrm{AX},{ }^{2} \boldsymbol{J}_{\mathrm{H}-\mathrm{H}}=12 \mathrm{~Hz},{ }^{3} \boldsymbol{J}_{\mathrm{Pt}-\mathrm{H}}\right.$ unresolved, $\left.4 \mathrm{H}, \mathrm{CH}_{2} \mathrm{~N}\right), 6.69\left(\mathrm{t},{ }^{3} J_{\mathrm{H}-\mathrm{H}}=8 \mathrm{~Hz}, 2 \mathrm{H}, \mathrm{NaphH}-7\right)$, $6.97\left(\mathrm{t},{ }^{3} J_{\mathrm{H}-\mathrm{H}}=8 \mathrm{~Hz}, 2 \mathrm{H}, \mathrm{NaphH}-6\right), 7.26\left(\mathrm{~d},{ }^{3} J_{\mathrm{H}-\mathrm{H}}=8 \mathrm{~Hz}\right.$, 
$2 \mathrm{H}, \mathrm{NaphH}), 7.66\left(\mathrm{~d},{ }^{3} J_{\mathrm{H}-\mathrm{H}}=8 \mathrm{~Hz}, 4 \mathrm{H}, \mathrm{NaphH}\right), 8.20\left(\mathrm{~d},{ }^{3} \boldsymbol{J}_{\mathrm{H}-\mathrm{H}}\right.$ $=8 \mathrm{~Hz}, 2 \mathrm{H}, \mathrm{NaphH}-8) .{ }^{13} \mathrm{C}\left\{{ }^{1} \mathrm{H}\right\} \mathrm{NMR}\left(\mathrm{C}_{6} \mathrm{D}_{6}\right): \delta 47.5$ and 50.1 $\left(\mathrm{NCH}_{3}\right), 75.0\left({ }^{2} J_{\mathrm{Pt}-\mathrm{C}}=60 \mathrm{~Hz}, \mathrm{CH}_{2} \mathrm{~N}\right), 121.1\left({ }^{3} J_{\mathrm{Pt}-\mathrm{C}}=47 \mathrm{~Hz}\right)$, $123.4,123.7,124.8,129.3,133.3\left({ }^{3} J_{\mathrm{Pt}-\mathrm{C}}=54 \mathrm{~Hz}\right), 135.4\left({ }^{3} \boldsymbol{J}_{\mathrm{Pt}-\mathrm{C}}\right.$ $=92 \mathrm{~Hz}), 141.6,142.9,143.9\left({ }^{1} \mathrm{~J}_{\mathrm{Pt}-\mathrm{C}}=1133 \mathrm{~Hz}, \mathrm{C}_{\mathrm{ipso}}\right) .{ }^{195} \mathrm{Pt}-$ $\left\{{ }^{1} \mathrm{H}\right\} \operatorname{NMR}\left(\mathrm{C}_{6} \mathrm{D}_{6}\right): \delta-3439.9$. Anal. Calcd for $\mathrm{C}_{26} \mathrm{H}_{28} \mathrm{~N}_{2} \mathrm{Pt}$ : C, $55.41 ; \mathrm{H}, 5.01 ; \mathrm{N}, 4.97$. Found: $\mathrm{C}, 55.28 ; \mathrm{H}, 4.96 ; \mathrm{N}, 4.89$. trans14: ${ }^{1} \mathrm{H}$ NMR $\left(\mathrm{C}_{6} \mathrm{D}_{6}\right): \delta 2.44\left(\mathrm{~s}, 6 \mathrm{H}, \mathrm{NCH}_{3}\right), 2.47\left(\mathrm{~s}, 6 \mathrm{H}, \mathrm{NCH}_{3}\right)$, $3.03 / 4.69\left(\mathrm{AX},{ }^{2} J_{\mathrm{H}-\mathrm{H}}=13 \mathrm{~Hz}, 4 \mathrm{H}, \mathrm{CH}_{2} \mathrm{~N}\right), 7.43\left(\mathrm{t},{ }^{3} \boldsymbol{J}_{\mathrm{H}-\mathrm{H}}=6\right.$ $\mathrm{Hz}, 2 \mathrm{H}, \mathrm{NaphH}), 7.74\left(\mathrm{~d},{ }^{3} \boldsymbol{J}_{\mathrm{H}-\mathrm{H}}=8 \mathrm{~Hz}, 2 \mathrm{H}, \mathrm{NaphH}\right) .{ }^{13} \mathrm{C}\left\{{ }^{1} \mathrm{H}\right\}$ $\operatorname{NMR}\left(\mathrm{C}_{6} \mathrm{D}_{6}\right): \delta 51.5\left(\mathrm{NCH}_{3}\right), 56.0\left(\mathrm{NCH}_{3}\right), 80.5\left(\mathrm{CH}_{2} \mathrm{~N}\right), 121.1$ $\left({ }^{3} J_{\mathrm{Pt}-\mathrm{C}}=47 \mathrm{~Hz}\right), 123.5,123.6,124.5,132.2,133.9,141.2,144.6$, $174.4\left(\mathrm{C}_{\mathrm{ipso}}\right)$. One aromatic signal remained unresolved due to overlap with solvent signals. ${ }^{195} \mathrm{Pt}\left\{{ }^{1} \mathrm{H}\right\} \mathrm{NMR}\left(\mathrm{C}_{6} \mathrm{D}_{6}\right): \delta-2826.6$.

General Procedure for Isomerization Reactions. A mixture of the cis- and trans-isomers of 10, 12, 13, or $14(0.6$ $\mathrm{mmol})$ was dissolved in toluene $(40 \mathrm{~mL})$ and refluxed for several hours. The conversion of trans-12 and trans-13 was complete within $3-5 \mathrm{~h}$, whereas the conversion of trans-10 and trans-14 was only complete in $16 \mathrm{~h}$ (determined by ${ }^{1} \mathrm{H}$ NMR spectroscopy). After full isomerization the reaction mixtures were allowed to cool to room temperature, after which the solvent was removed in vacuo. The solid residues were washed with $\mathrm{Et}_{2} \mathrm{O}(5 \mathrm{~mL}, 2 \times)$. Yield of cis-10: $83 \%$, cis-12: 53\%, cis-13: $77 \%$, cis-14: $79 \%$.

trans-[PtCl$\left.\left(\mathrm{C}_{6} \mathrm{H}_{3} \mathrm{Br}-4-\left\{\mathrm{CH}_{2} \mathbf{N M e}_{2}\right\}-2\right)\left(\mathrm{SEt}_{2}\right)\right]$ (17). The synthesis of $\mathbf{1 7}$ is similar to the synthesis of $\mathbf{1 0}$, starting from $\mathbf{5}$ $(1.28 \mathrm{~g}, 3.8 \mathrm{mmol})$ in $\mathrm{Et}_{2} \mathrm{O}(40 \mathrm{~mL})$ with $n$-BuLi $(2.3 \mathrm{~mL}, 1.6$ $\mathrm{M}$ in hexane, $3.7 \mathrm{mmol}, 0.98$ equiv) and $\left[\mathrm{PtCl}_{2}\left(\mathrm{SEt}_{2}\right)_{2}\right](1.62 \mathrm{~g}$, $3.63 \mathrm{mmol}, 0.97$ equiv). The reaction mixture was concentrated in vacuo, dissolved in $\mathrm{CH}_{2} \mathrm{Cl}_{2}$, and filtered over Celite. After removal of the solvent in vacuo and washing with pentane (5 $\mathrm{mL}, 3 \times), \mathbf{1 7}$ was obtained as an off-white powder, with $5 \%$ of cis-10 as impurity. The complexes were separated by column chromatography over silica $\left(\mathrm{CH}_{2} \mathrm{Cl}_{2} /\right.$ pentane $=90: 10, R_{f}(\mathbf{1 7})$ $=0.57, R_{f}($ cis-10 $\left.)=0.73\right)$. Yield of 17: $1.47 \mathrm{~g}(2.75 \mathrm{mmol}, 76 \%)$. ${ }^{1} \mathrm{H}$ NMR $\left(\mathrm{CDCl}_{3}\right): \delta 1.38\left(\mathrm{~m}, 6 \mathrm{H}, \mathrm{SCH}_{2} \mathrm{CH}_{3}\right), 2.86(\mathrm{~m}, 2 \mathrm{H}$, $\left.\mathrm{SCH} \mathrm{CH}_{3}\right), 2.98\left(\mathrm{~s},{ }^{3} J_{\mathrm{Pt}-\mathrm{H}}=34.8 \mathrm{~Hz}, 6 \mathrm{H}, \mathrm{NCH}_{3}\right), 3.27(\mathrm{~m}, 2 \mathrm{H}$, $\left.\mathrm{SCH}_{2} \mathrm{CH}_{3}\right), 3.90\left(\mathrm{~s},{ }^{3} J_{\mathrm{Pt}-\mathrm{H}}=41.7 \mathrm{~Hz}, 2 \mathrm{H}, \mathrm{CH}_{2} \mathrm{~N}\right), 7.09\left(\mathrm{~d},{ }^{2} J_{\mathrm{H}-\mathrm{H}}\right.$ $=8 \mathrm{~Hz}, 1 \mathrm{H}, \operatorname{ArH}-5), 7.16(\mathrm{~s}, 1 \mathrm{H}, \mathrm{ArH}-3), 7.26\left(\mathrm{~d},{ }^{2} J_{\mathrm{H}-\mathrm{H}}=8\right.$ $\left.\mathrm{Hz},{ }^{3} J_{\mathrm{Pt}-\mathrm{H}}=60 \mathrm{~Hz} 1 \mathrm{H}, \mathrm{ArH}-6\right),{ }^{13} \mathrm{C}\left\{{ }^{1} \mathrm{H}\right\} \mathrm{NMR}\left(\mathrm{CDCl}_{3}\right): \delta 13.3$ $\left(\mathrm{SCH}_{2} \mathrm{CH}_{3}\right), 31.9\left(\mathrm{SCH}_{2} \mathrm{CH}_{3}\right), 52.4\left(\mathrm{NCH}_{3}\right), 74.5\left({ }^{2} J_{\mathrm{Pt}-\mathrm{C}}=51\right.$ $\left.\mathrm{Hz}, \mathrm{CH}_{2} \mathrm{~N}\right), 117.3(\mathrm{ArC}-4), 124.6\left({ }^{3} J_{\mathrm{Pt}-\mathrm{C}}=37 \mathrm{~Hz}, \mathrm{ArC}-3\right)$, $128.3\left({ }^{3} J_{\mathrm{Pt}-\mathrm{C}}=62 \mathrm{~Hz}, \mathrm{ArC}-5\right), 133.3\left({ }^{1} J_{\mathrm{Pt}-\mathrm{C}}=1077 \mathrm{~Hz}, \mathrm{ArC}_{\mathrm{ipso}}\right)$, $133.5\left({ }^{2} J_{\mathrm{Pt}-\mathrm{C}}=68 \mathrm{~Hz}\right.$, ArC-6), $149.6(\mathrm{ArC}-2) .{ }^{195} \mathrm{Pt}\left\{{ }^{1} \mathrm{H}\right\}$ NMR $\left(\mathrm{CDCl}_{3}\right): \delta-3699.8$. Anal. Calcd for $\mathrm{C}_{13} \mathrm{H}_{21} \mathrm{BrClN}-$ PtS: C, 29.25; H, 3.97; N, 2.62. Found: C, 29.23; H, 3.89; N, 2.49 .

Reaction of 17 with 16 to Yield 10. To a solution of 5 $(0.25 \mathrm{~g}, 0.74 \mathrm{mmol})$ in $\mathrm{Et}_{2} \mathrm{O}(20 \mathrm{~mL})$ was added $n-\mathrm{BuLi}(1.6 \mathrm{M}$ in hexane, $0.45 \mathrm{~mL}, 0.72 \mathrm{mmol}, 1.0$ equiv) at $-78{ }^{\circ} \mathrm{C}$. After 5 min, solid 17 ( $0.36 \mathrm{~g}, 0.67 \mathrm{mmol}, 0.9$ equiv) was added and the mixture was allowed to warm to room temperature and stirred for $3 \mathrm{~h}$. After standard workup, $0.25 \mathrm{~g}$ of $\mathbf{1 0}(0.40 \mathrm{mmol}$, $60 \%$ ) was obtained in a cis/trans ratio of 80:20, after analysis by NMR spectroscopy.

[PtI $\left.{ }_{2}\left(\mathrm{C}_{6} \mathrm{H}_{3} \mathrm{Br}-4-\left\{\mathrm{CH}_{2} \mathrm{NMe}_{2}\right\}-2\right)_{2}\right]$ (18). Complex cis-10 (33 mg, $0.054 \mathrm{mmol}$ ) was dissolved in $\mathrm{CH}_{2} \mathrm{Cl}_{2}(1 \mathrm{~mL})$. To this $\mathrm{I}_{2}(4.0 \mathrm{~mL}, 0.014 \mathrm{M}$ in toluene, $0.056 \mathrm{mmol}, 1.0$ equiv) was added dropwise. A dark red-orange precipitate was formed immediately. After $1 \mathrm{~h}$ stirring, the precipitate was isolated, washed with $\mathrm{Et}_{2} \mathrm{O}(5 \mathrm{~mL}, 2 \times)$, and dried in vacuo. Yield of 18: $45 \mathrm{mg}(0.051 \mathrm{mmol}, 94 \%) .{ }^{1} \mathrm{H} \mathrm{NMR}\left(\mathrm{CDCl}_{3}\right)$ : $\delta$ $2.78\left(\mathrm{~s},{ }^{3} J_{\mathrm{Pt}-\mathrm{H}}=10 \mathrm{~Hz}, 12 \mathrm{H}, \mathrm{NCH}_{3}\right), 4.04\left(\mathrm{~s},{ }^{3} J_{\mathrm{Pt}-\mathrm{H}}=11 \mathrm{~Hz}\right.$, $\left.4 \mathrm{H}, \mathrm{CH}_{2} \mathrm{~N}\right), 7.07-7.23(\mathrm{~m}, 6 \mathrm{H}, \mathrm{ArH})$. Anal. Calcd for $\mathrm{C}_{18} \mathrm{H}_{22}$ $\mathrm{Br}_{2} \mathrm{I}_{2} \mathrm{~N}_{2} \mathrm{Pt}$ : C, 24.71; H, 2.53; N, 3.20. Found: C, 24.86; H, 2.47; $\mathrm{N}, 3.12$.

cis-[Pt $\left(\eta^{1}-\mathrm{C}_{6} \mathrm{H}_{3} \mathrm{Br}-4-\left\{\mathrm{CH}_{2} \mathrm{NMe}_{2}\right\}-2\right)_{2}\left(\eta^{2}\right.$-dppp)] (19). To a solution of cis-10 $(63.6 \mathrm{mg}, 102 \mu \mathrm{mol})$ in $\mathrm{CH}_{2} \mathrm{Cl}_{2}(6 \mathrm{~mL})$ was added dppp (42.2 mg, $102 \mu \mathrm{mol}, 1.0$ equiv) at room temperature. The solution was stirred for $4 \mathrm{~h}$ at room temperature, after which the solvent was evaporated. The white product was purified by precipitation from a $\mathrm{CH}_{2} \mathrm{Cl}_{2}$ /pentane mixture. Yield of 19: $64.1 \mathrm{mg}(62 \mu \mathrm{mol}, 61 \%)$. Crystals (colorless needles) were obtained by cooling a saturated solution of 19 in $\mathrm{CH}_{2} \mathrm{Cl}_{2}$ at 4 ${ }^{\circ} \mathrm{C} .{ }^{1} \mathrm{H}$ NMR $\left(\mathrm{CDCl}_{3}\right): \delta 2.00\left(\mathrm{~m}, 2 \mathrm{H}, \mathrm{P}\left(\mathrm{CH}_{2}\right)_{3} \mathrm{P}\right) 2.08(\mathrm{~s}, 12 \mathrm{H}$, $\left.\mathrm{NCH}_{3}\right), 2.41\left(\mathrm{~m}, 2 \mathrm{H}, \mathrm{P}\left(\mathrm{CH}_{2}\right)_{3} \mathrm{P}\right), 2.56\left(\mathrm{~m}, 2 \mathrm{H}, \mathrm{P}\left(\mathrm{CH}_{2}\right)_{3} \mathrm{P}\right), 2.73 /$ $3.88\left(\mathrm{AX},{ }^{2} J_{\mathrm{H}-\mathrm{H}}=14 \mathrm{~Hz}, 4 \mathrm{H}, \mathrm{CH}_{2} \mathrm{~N}\right), 6.58\left(\mathrm{~d},{ }^{3} J_{\mathrm{H}-\mathrm{H}}=6 \mathrm{~Hz}\right.$, $2 \mathrm{H}, \mathrm{ArH}), 6.86(\mathrm{~m}, 4 \mathrm{H}, \mathrm{PPh}), 6.99(\mathrm{~s}, 2 \mathrm{H}, \mathrm{ArH}-3), 7.12(\mathrm{~m}, 6 \mathrm{H}$, $\mathrm{PPh}), 7.28$ (m, 2H, ArH), 7.44 (m, 6H, PPh), $7.86(\mathrm{~m}, 4 \mathrm{H}, \mathrm{PPh})$. ${ }^{13} \mathrm{C}\left\{{ }^{1} \mathrm{H}\right\}$ NMR $\left(\mathrm{CDCl}_{3}\right): \delta 14.3,31.8$, and $22.8\left(\mathrm{P}\left(\mathrm{CH}_{2}\right)_{3} \mathrm{P}\right), 45.9$ $\left(\mathrm{NCH}_{3}\right), 65.7\left({ }^{3} J_{\mathrm{Pt}-\mathrm{H}}=70 \mathrm{~Hz}, \mathrm{CH}_{2} \mathrm{~N}\right), 116.7(\mathrm{ArC}-4), 127.2$ $\left({ }^{3} J_{\mathrm{Pt}-\mathrm{C}}=66 \mathrm{~Hz}, \mathrm{ArC}-3\right), 127.9,128.6,129.2\left({ }^{3} \boldsymbol{J}_{\mathrm{Pt}-\mathrm{C}}=49 \mathrm{~Hz}\right.$, ArC-5), 129.7, $130.8131 .8,134.0,139.5\left({ }^{2} J_{\mathrm{Pt}-\mathrm{C}}=32 \mathrm{~Hz}, \mathrm{ArC}-\right.$ 6), 147.0 (ArC-2), 155.7 (dd, ${ }^{2} J_{\mathrm{P}-\mathrm{C}}=98 \mathrm{~Hz}$ (trans), ${ }^{2} J_{\mathrm{P}-\mathrm{C}}=15$ $\mathrm{Hz}($ cis $\left.), \mathrm{C}_{\mathrm{ipso}}\right) .{ }^{31} \mathrm{P} \mathrm{NMR}\left(\mathrm{CDCl}_{3}\right): \delta-4.46\left({ }^{1} J_{\mathrm{Pt}-\mathrm{P}}=1723 \mathrm{~Hz}\right)$. ${ }^{195} \mathrm{Pt}\left\{{ }^{1} \mathrm{H}\right\} \mathrm{NMR}\left(\mathrm{CDCl}_{3}\right): \delta-4479.4\left(\mathrm{~d},{ }^{1} J_{\mathrm{Pt}-\mathrm{P}}=1744 \mathrm{~Hz}\right)$. Anal. Calcd for $\mathrm{C}_{45} \mathrm{H}_{48} \mathrm{~N}_{2} \mathrm{P}_{2} \mathrm{Br}_{2} \mathrm{Pt}$ : C, $52.29 ; \mathrm{H}, 4.68 ; \mathrm{N}, 2.71$. Found: C, 52.34; H, 4.61; N, 2.67.

cis-[Pt $\left.\left\{\mathrm{C}_{6} \mathbf{H}_{2}\left(\mathbf{S n M e}_{3}\right)-\mathbf{4}-\left(\mathrm{CH}_{2} \mathbf{N M e}_{2}\right)_{2}-\mathbf{2 , 5}\right\}_{2}\right]$ (20). A solution of cis-12 $(67 \mathrm{mg}, 0.09 \mathrm{mmol})$ in THF $(15 \mathrm{~mL})$ was cooled to $-35^{\circ} \mathrm{C}$, after which $n$-BuLi $(0.36 \mathrm{mmol}, 0.53 \mathrm{M}$ in hexane, 0.7 $\mathrm{mL}, 4.0$ equiv) was added. After $15 \mathrm{~min}$ at this temperature, the reaction mixture was quenched with $\left[\mathrm{SnBrMe}_{3}\right](0.4 \mathrm{mmol}$, $0.50 \mathrm{M}$ in THF, $0.8 \mathrm{~mL}, 4.4$ equiv). The mixture was stirred for $1 \mathrm{~h}$ at room temperature and extracted with a $\mathrm{CH}_{2} \mathrm{Cl}_{2} /$ brine mixture. A white solid was obtained after evaporation of the solvents, which was purified using column chromatography over silica $\left(\mathrm{CH}_{2} \mathrm{Cl}_{2} / \mathrm{NEt}_{3}=97: 3\right)$. Yield of 20: $53 \mathrm{mg}(0.06$ mmol, 67\%). ${ }^{1} \mathrm{H}$ NMR $\left(\mathrm{C}_{6} \mathrm{D}_{6}\right): \delta 0.45\left(\mathrm{~s},{ }^{2} J_{\mathrm{Sn}-\mathrm{H}}=53 \mathrm{~Hz}, 18 \mathrm{H}\right.$, $\left.\mathrm{SnCH}_{3}\right), 2.06\left(\mathrm{~s},{ }^{2} J_{\mathrm{Sn}-\mathrm{H}}\right.$ unresolved, $\left.12 \mathrm{H}, \mathrm{CH}_{2} \mathrm{NCH}_{3}-5\right), 2.13(\mathrm{~s}$, $\left.12 \mathrm{H}, \mathrm{CH}_{2} \mathrm{NCH}_{3}-2\right), 3.44\left(\mathrm{~s},{ }^{2} J_{\mathrm{Sn}-\mathrm{H}}=\right.$ unresolved, $4 \mathrm{H}, \mathrm{CH}_{2} \mathrm{NCH}_{3-}$ 5), $3.51\left(\mathrm{~s}, 4 \mathrm{H}, \mathrm{CH}_{2} \mathrm{NCH}_{3}-2\right), 7.53\left(\mathrm{~s},{ }^{3} J_{\mathrm{Sn}-\mathrm{H}}=56 \mathrm{~Hz}, 2 \mathrm{H}, \mathrm{ArH}-\right.$ 3), $7.82\left(\mathrm{~s},{ }^{3} \mathrm{~J}_{\mathrm{Pt}-\mathrm{H}}=20 \mathrm{~Hz},{ }^{4} J_{\mathrm{Sn}-\mathrm{H}}=62 \mathrm{~Hz}, 2 \mathrm{H}, \mathrm{ArH}-6\right) .{ }^{13} \mathrm{C}\left\{{ }^{1} \mathrm{H}\right\}$ $\operatorname{NMR}\left(\mathrm{C}_{6} \mathrm{D}_{6}\right): \delta-7.2\left({ }^{1} J_{\mathrm{Sn}-\mathrm{C}}=338\right.$ and $\left.353 \mathrm{~Hz}, \mathrm{SnCH}_{3}\right), 45.3$ $\left(\mathrm{CH}_{2} \mathrm{NCH}_{3}-2\right), 49.5\left(\mathrm{CH}_{2} \mathrm{NCH}_{3}-5\right), 67.0\left(\mathrm{CH}_{2} \mathrm{NCH}_{3}-2\right), 73.6$ $\left(\mathrm{CH}_{2} \mathrm{NCH}_{3}-5\right), 129.5,133.7,140.5,142.3,142.8,146.9 .{ }^{195} \mathrm{Pt}-$ $\left\{{ }^{1} \mathrm{H}\right\} \mathrm{NMR}\left(\mathrm{CDCl}_{3}\right): \delta-3412.1$. Anal. Calcd for $\mathrm{C}_{30} \mathrm{H}_{54} \mathrm{~N}_{4}$ $\mathrm{PtSn}_{2}$ : C, 39.89; H, 6.03; N, 6.20. Found: C, 39.83; H, 5.95; $\mathrm{N}, 6.16$.

3,5-Bis(tert-butylsulfidomethyl)bromobenzene (22). Sodium (1.14 g, $49.6 \mathrm{mmol})$ was dissolved in EtOH $(150 \mathrm{~mL})$, and $t$-BuSH (5.5 mL, $48.8 \mathrm{mmol}, 0.98$ equiv) was added. This mixture was heated to reflux for $30 \mathrm{~min}$, after which $\mathbf{2 1}(8.35$ g, $24.35 \mathrm{mmol}, 0.50$ equiv) was added. The reaction was heated to reflux for $16 \mathrm{~h}$. The white suspension was concentrated, extracted with pentane, washed with brine, dried over $\mathrm{MgSO}_{4}$, and evaporated in vacuo. Yield of $\mathbf{2 2}$ as an off-white solid: 7.79 $\mathrm{g}(21.6 \mathrm{mmol}, 89 \%) .{ }^{1} \mathrm{H} \mathrm{NMR}\left(\mathrm{CDCl}_{3}\right): \delta 1.33\left(\mathrm{~s}, 18 \mathrm{H}, \mathrm{CCH}_{3}\right)$, $3.68\left(\mathrm{~s}, 4 \mathrm{H}, \mathrm{CH}_{2} \mathrm{~S}\right), 7.25(\mathrm{~s}, 1 \mathrm{H}, \mathrm{ArH}-4), 7.35$ (s, 2H, ArH-2,6). ${ }^{13} \mathrm{C}\left\{{ }^{1} \mathrm{H}\right\}$ NMR $\left(\mathrm{CDCl}_{3}\right): \quad \delta 31.0\left(\mathrm{CCH}_{3}\right), 32.9\left(\mathrm{CH}_{2} \mathrm{~S}\right), 43.2$ $\left(\mathrm{CCH}_{3}\right.$ ), 122.4 (ArC-1), 128.4 (ArC-4), 130.5 (ArC-2,6), 141.1 (ArC-3,5). Anal. Calcd for $\mathrm{C}_{16} \mathrm{H}_{25} \mathrm{BrS}_{2}$ : C, 53.17; H, 6.97; S, 17.74. Found: C, 53.25; H, 6.89; S, 17.65 .

3,5-Bis(tert-butylsulfidomethyl)pinacolboranebenzene (23). To a solution of 22 (4.16 g, $11.5 \mathrm{mmol})$ in $\mathrm{Et}_{2} \mathrm{O}(100$ $\mathrm{mL}$ ) was added $t$-BuLi (16 mL, $24 \mathrm{mmol}, 2.1$ equiv, $1.5 \mathrm{M}$ in hexane) at $-78{ }^{\circ} \mathrm{C}$. The reaction mixture was stirred at this temperature for $20 \mathrm{~min}$, after which $\mathrm{B}(\mathrm{OMe})_{3}(2.0 \mathrm{~mL}, 17.5$ mmol, 1.5 equiv) was added dropwise. The mixture was slowly warmed to room temperature overnight. Pinacol (1.43 g, 12.1 mmol, 1.1 equiv) was added, followed by HOAc $(0.7 \mathrm{~mL}, 12.1$ mmol, 1.1 equiv) after $10 \mathrm{~min}$. The reaction mixture was stirred for $1 \mathrm{~h}$ and filtered, and the solvents were evaporated in vacuo. The product was washed with $\mathrm{MeOH}(10 \mathrm{~mL}, 2 \times)$ and evaporated to dryness, after which $\mathbf{2 3}$ was obtained as a white solid. Yield: $3.31 \mathrm{~g}(8.1 \mathrm{mmol}, 70 \%) .{ }^{1} \mathrm{H} \mathrm{NMR}\left(\mathrm{CDCl}_{3}\right)$ : $\delta 1.33\left(\mathrm{~s}, 12 \mathrm{H}, \mathrm{OCCH}_{3}\right), 1.35\left(\mathrm{~s}, 18 \mathrm{H}, \mathrm{SCCH}_{3}\right), 3.74(\mathrm{~s}, 4 \mathrm{H}$, $\left.\mathrm{CH}_{2} \mathrm{~S}\right), 7.46$ (s, $\left.1 \mathrm{H}, \mathrm{ArH}-4\right), 7.62$ (s, 2H, ArH-2,6). ${ }^{13} \mathrm{C}\left\{{ }^{1} \mathrm{H}\right\}$ NMR $\left(\mathrm{CDCl}_{3}\right): \delta 25.0\left(\mathrm{OCCH}_{3}\right), 31.0\left(\mathrm{SCCH}_{3}\right), 33.3\left(\mathrm{CH}_{2} \mathrm{~S}\right), 43.0$ $\left(\mathrm{SCCH}_{3}\right), 83.9\left(\mathrm{OCCH}_{3}\right), 132.8,134.0,138.0$. Anal. Calcd for 
$\mathrm{C}_{22} \mathrm{H}_{37} \mathrm{BO}_{2} \mathrm{~S}_{2}$ : C, 64.69; H, 9.13; S, 15.70. Found: C, 64.70; H, 8.92; S, 15.51 .

cis -[Pt(dmba-4-SCS $\{\boldsymbol{t}$-Bu $\left.\})_{2}\right]$ (24). Complex cis-10 (280 $\mathrm{mg}, 0.45 \mathrm{mmol}$ ), 23 (391 $\mathrm{mg}, 0.96 \mathrm{mmol}, 2.1$ equiv), [ $\mathrm{PdCl}_{2^{-}}$ dppf] (21 mg, $0.029 \mathrm{mmol}, 6 \%$ ), and $\mathrm{Na}_{2} \mathrm{CO}_{3}$ (266 mg, 2.51 mmol, 5.6 equiv) were introduced in a Schlenk flask, which was evacuated for $30 \mathrm{~min}$. To this, a degassed mixture of DME (10 mL), THF $(10 \mathrm{~mL})$, and $\mathrm{H}_{2} \mathrm{O}(10 \mathrm{~mL})$ was added. The reaction mixture was stirred at $70{ }^{\circ} \mathrm{C}$ until the reaction was complete $( \pm 3 \mathrm{~h})$. The reaction mixture was cooled to room temperature, extracted with $\mathrm{CH}_{2} \mathrm{Cl}_{2}(50 \mathrm{~mL})$, dried over $\mathrm{MgSO}_{4}$, and evaporated to dryness. The product was purified by column chromatography (basic alumina, $\mathrm{CH}_{2} \mathrm{Cl}_{2}, R_{f}=1.0$ ) and subsequently washed with hexane and $\mathrm{Et}_{2} \mathrm{O}(5 \mathrm{~mL}, 3 \times)$. Complex 24 was isolated as a white solid. Yield: $0.36 \mathrm{~g}(0.35$ mmol, 78\%). ${ }^{1} \mathrm{H} \mathrm{NMR}\left(\mathrm{CDCl}_{3}\right): \delta 1.37\left(\mathrm{~s}, 36 \mathrm{H}, \mathrm{CCH}_{3}\right), 2.84(\mathrm{~s}$, $\left.12 \mathrm{H}, \mathrm{NCH}_{3}\right), 3.80\left(\mathrm{~s}, 8 \mathrm{H}, \mathrm{CH}_{2} \mathrm{~S}\right), 3.95\left(\mathrm{~s}, 4 \mathrm{H}, \mathrm{CH}_{2} \mathrm{~N}\right), 7.25(\mathrm{~m}$, $6 \mathrm{H}, \mathrm{ArH}), 7.46(\mathrm{~s}, 4 \mathrm{H}, \mathrm{ArH}-8,12), 7.55\left(\mathrm{~d},{ }^{3} J_{\mathrm{H}-\mathrm{H}}=9 \mathrm{~Hz}, 2 \mathrm{H}\right.$, ArH-6). ${ }^{13} \mathrm{C}\left\{{ }^{1} \mathrm{H}\right\}$ NMR $\left(\mathrm{CDCl}_{3}\right): \delta 31.1\left(\mathrm{CCH}_{3}\right), 33.6\left(\mathrm{CH}_{2} \mathrm{~S}\right)$, $43.0\left(\mathrm{CCH}_{3}\right), 50.3\left(\mathrm{NCH}_{3}\right), 73.8\left(\mathrm{CH}_{2} \mathrm{~N}\right), 120.0,124.7,125.9$, $127.6,134.8,138.6,139.0,139.2\left(\mathrm{C}_{\mathrm{ipso}}\right), 142.6,148.0 .{ }^{195} \mathrm{Pt}\left\{{ }^{1} \mathrm{H}\right\}$ NMR $\left(\mathrm{CDCl}_{3}\right): \delta-3385.8$. Anal. Calcd for $\mathrm{C}_{50} \mathrm{H}_{72} \mathrm{~N}_{2} \mathrm{~S}_{4} \mathrm{Pt}: \mathrm{C}$, 58.62; H, 7.08; N, 2.73; S, 12.52. Found: C, 58.47; H, 7.19; N, $2.78 ; \mathrm{S}, 12.46$.

cis-[Pt(dmba-4-\{PdCl(SCS $\left.\{t-B u\})\})_{2}\right]$ (25). To a solution of $24(145 \mathrm{mg}, 0.14 \mathrm{mmol})$ in degassed MeCN (30 mL) was added $\left[\mathrm{Pd}(\mathrm{NCMe})_{4}\right]\left(\mathrm{BF}_{4}\right)_{2}(125 \mathrm{mg}, 0.28 \mathrm{mmol}, 2.0$ equiv). After 10 min $\mathrm{NEt}_{3}(39 \mu \mathrm{L}, 0.28 \mathrm{mmol}, 2.0$ equiv) was added. The reaction mixture was heated at reflux for $2 \mathrm{~h}$, cooled to room temperature, and filtered over Celite. The mixture was diluted with $\mathrm{CH}_{2} \mathrm{Cl}_{2}(50 \mathrm{~mL})$ and stirred with brine $(20 \mathrm{~mL})$ for $1 \mathrm{~h}$. The organic layer was collected, dried over $\mathrm{MgSO}_{4}$, and evaporated to dryness. A concentrated solution of the remaining solid in $\mathrm{CH}_{2} \mathrm{Cl}_{2}$ was prepared. Slow distillation of $\mathrm{Et}_{2} \mathrm{O}$ into this mixture afforded pure $\mathbf{2 5}$ as light yellow crystals or a powder. Crystals suitable for X-ray structure determination were obatined by cooling a saturated solution of $\mathbf{2 5}$ in a mixture of $\mathrm{CH}_{2} \mathrm{Cl}_{2} / \mathrm{Et}_{2} \mathrm{O}(10: 1)$ at $-30{ }^{\circ} \mathrm{C}$. Yield: $102 \mathrm{mg}$ $\left.(0.078 \mathrm{mmol}, 56 \%) .{ }^{1} \mathrm{H} \mathrm{NMR}\left(\mathrm{CDCl}_{3}\right): \delta 1.61\left(\mathrm{~s}, 36 \mathrm{H}, \mathrm{CCH}_{3}\right)_{3}\right)$, $2.84\left(\mathrm{~s}, 12 \mathrm{H}, \mathrm{NCH}_{3}\right), 3.94\left(\mathrm{~s}, 4 \mathrm{H}, \mathrm{CH}_{2} \mathrm{~N}\right), 4.21\left(\mathrm{~s}, 8 \mathrm{H}, \mathrm{CH}_{2} \mathrm{~S}\right)$, $7.18(\mathrm{~m}, 8 \mathrm{H}, \mathrm{ArH}), 7.52\left(\mathrm{~d},{ }^{3} J_{\mathrm{H}-\mathrm{H}}=7 \mathrm{~Hz}, 2 \mathrm{H}, \mathrm{ArH}-6\right) .{ }^{13} \mathrm{C}\left\{{ }^{1} \mathrm{H}\right\}$ $\operatorname{NMR}\left(\mathrm{CDCl}_{3}\right): \delta 30.8\left(\mathrm{CCH}_{3}\right), 42.8\left(\mathrm{CCH}_{3}\right), 50.3\left(\mathrm{NCH}_{3}\right), 52.1$ $\left(\mathrm{CH}_{2} \mathrm{~S}\right), 73.8\left(\mathrm{CH}_{2} \mathrm{~N}\right), 119.6,119.7,124.2,134.5,138.6,139.2$ $\left(\mathrm{C}_{\text {ipso }}, \mathrm{Pt}\right), 148.3,150.3,157.1\left(\mathrm{C}_{\text {ipso }}, \mathrm{Pd}\right) .{ }^{195} \mathrm{Pt}\left\{{ }^{1} \mathrm{H}\right\} \mathrm{NMR}$ $\left(\mathrm{CDCl}_{3}\right): \delta-3381.4$. Anal. Calcd for $\mathrm{C}_{50} \mathrm{H}_{70} \mathrm{~N}_{2} \mathrm{~S}_{4} \mathrm{Cl}_{2} \mathrm{PtPd}_{2}$ : C, 45.98; H, 5.40; N, 2.14; S, 9.82. Found: C, 46.08; H, 3.84; N, $2.03 ; \mathrm{S}, 9.74$.

Acknowledgment. M.L. and A.L.S. kindly acknowledge the Netherlands Organization for Scientific Research (NWO) for financial support.

Supporting Information Available: CIF files for the $\mathrm{X}$-ray structural data of complexes cis-12· Et ${ }_{2} \mathrm{O}$, cis-14· $x \mathrm{C}_{6} \mathrm{H}_{6}$, 19, and $25 \cdot x \mathrm{CH}_{2} \mathrm{Cl}_{2}$. This material is free of charge via the Internet at http://pubs.acs.org.

OM050144S 